Pre-print: French JR, Burningham H, Thornhill G, Nicholls RJ (2016) Integrating estuarine, coastal and inner shelf sediment systems in a common conceptual framework as a basis for participatory shoreline management. In: Meadows M, Lin J-C (eds.) Geomorphology and society. Springer (in press).

\title{
Integrating estuarine, coastal and inner shelf sediment systems in a common conceptual framework as a basis for participatory shoreline management
}

\author{
Jon R French, Helene Burningham, Gillian D Thornhill and Robert J Nicholls
}

\begin{abstract}
Coastal and estuarine margins are home to an increasing proportion of the global human population and its activities. Within this context, landforms play a critical role in mediating the translation of erosion and flood risk to human receptors in environmental settings that are vulnerable to the likely impacts of climate change. Predicting how coastal and estuarine landforms will evolve in response to changes in sea level and wave climate is thus of considerable importance. This is naturally a modelling problem but previous efforts have often failed to translate generic principles into models that do justice to the placespecific interactions between contemporary processes, antecedent geology, sea level history, historical morphology, engineering interventions and, not least, broader societal concerns. Progress clearly requires better models but, as we argue here, more sophisticated conceptual frameworks are also needed. Accordingly, we outline a new Coastal and Estuarine System Mapping (CESM) approach that captures the configuration of estuarine, coastal and inner shelf landform complexes within a unifying framework that also explicitly resolves the multitude of human interventions that influence shoreline change. An illustrative application to the Suffolk coast of eastern England demonstrates the potential of CESM to encourage a more participatory approach to regional shoreline management and the application of scientific understanding to the challenge of living with human and climate change impacts at the coast.
\end{abstract}

Key words: Coastal geomorphology, systems theory, ontology, conceptual model, coastal management

\section{Introduction}

Coastal and estuarine margins are home to an increasing proportion of the global human population and its activities (McGranahan et al. 2007; Lichter et al. 2011) and that over 200 million people are vulnerable to annual flooding during storms and surges (Nicholls 2011). The attendant potential for loss and damage to human lives and assets due to erosion, storm surges, extreme waves and tsunamis means that coasts, in the widest sense of the term, constitute one of the riskiest environments (Kron 2013). In the $21^{\text {st }}$ century, the challenge of continuing to manage these risks is exacerbated by the prospect of a significant increase in damage costs as the effects of widespread erosion and progressive inundation due to sediment deficits and subsidence combine with climate change impacts on sea-level and coastal wave climate. There is little realistic prospect of mitigating the rate of climate-driven sea-level rise over decadal scales given the substantial inertia of the coupled atmosphere, cryosphere and oceans (Nichols and Lowe 2004), and the prospect that annual coastal flood damage costs alone could potentially amount to between 0.3 and $9.3 \%$ of global GDP by 2100 (Hinkel et al. 2014) will likely stimulate a significant adaptation effort (Brown et al. 2014).

Historically, continuing advances in engineering capability have favoured protection as a strategy for adapting to erosion and flood risk (Charlier et al. 2011; Nicholls 2011; Nordstrom, 2014). The influence of engineered structures on shoreline dynamics is now pervasive (van Koningsveld et al. 2008; Brown et al. 2011; Bernatchez and Fraser 2012). The cumulative legacy 
Pre-print: French JR, Burningham H, Thornhill G, Nicholls RJ (2016) Integrating estuarine, coastal and inner shelf sediment systems in a common conceptual framework as a basis for participatory shoreline management. In: Meadows M, Lin J-C (eds.) Geomorphology and society. Springer (in press).

of intervention is such that, at the scale of the United States, rates of shoreline change along the open coast are strongly constrained by varying levels of development (Hapke et al. 2013). Naturally dynamic estuarine systems are similarly held away from natural equilibrium morphologies, in artificial meta-stable, states by extensive flood defences, training walls and inlet jetties (e.g. Huang et al. 2004; Smits et al. 2006; Wetzel et al. 2014). Efforts to secure and maintain socially acceptable levels of protection against erosion and flooding have latterly been conducted within a shoreline management paradigm (Nicholls et al. 2013) under which a traditional reliance on engineering has been supplemented by a growing awareness that coastal engineering problems are also geomorphological ones.

The role of geomorphologists in coastal engineering and shoreline management has stemmed partly from the realisation that erosion problems are typically rooted in interruptions of natural sediment pathways or constraints on sediment supply (Allen 1981; Kana 1995; Runyan and Griggs 2003; Hapke et al. 2010). This understanding is underpinned by the related concepts of the sediment budget (Bowen and Inman, 1966) and the littoral cell (Inman and Frautschy 1966; Davies 1974). Littoral cells are easily defined on compartmented bay-headland coasts (Shih and Komar, 1994; Storlazzi and Field 2000; Barnard et al. 2012), with divergences or convergences in transport flux or estuary inlets being used to structure the sediment system on more open coasts (Stapor 1973; Motyka and Brampton 1993; Bray et al 1995). Hierarchies of littoral cells provide a geomorphological framework for management planning at a wide range of scales that has clear advantages over schemes based primarily on administrative boundaries (Komar 1996; Cooper and Pethick 2005; Psuty and Pace 2009; Stul et al. 2012).

At the landform scale, coastal engineering has also undergone a shift in emphasis from a reliance on hard structures towards softer approaches that seek to work with, rather than against, natural processes of sediment movement. Structural interventions increasingly attempt to mimic natural features (e.g. Hsu et al. 2010), and the role of beaches, dunes and wetlands in dissipating wave energy and attenuating extreme water levels is widely appreciated (e.g. Hanley et al. 2014; Luo et al. 2015). Landforms are also integral to widely used conceptual models of erosion and flood risk. The Source-Pathway-Receptor model (Sayers et al. 2002; Narayan et al. 2012), for example, highlights the role of landforms as one of the pathways that mediate the transmission of flood risk from marine and fluvial sources to human receptors in low-lying areas (e.g. Batten et al., 2015). Given the extent to which the sources of risk are anticipated to change over the course of the $21^{\text {st }}$ century and beyond, it is important that we develop our understanding of how coastal morphology will evolve and how this will influence erosion and flood risk. In this context, the ability to quantitatively predict coastal morphological change at decadal to centennial scales thus assumes considerable importance.

Predictions of coastal change are often derived from analysis of historical behaviour on the premise that the future can somehow be extrapolated from the recent past. However, landform and sediment system behaviour is often highly non-linear (e.g. Werner, 2003) and past configurations often contain insufficient information to generate quantitative predictions of future behaviour (Gelbaum and Kaminisky 2010; French and Burningham 2013). Modelling of coastal morphological change has consequently become a very active area of research. However, devising robust mechanistic schemes capable of resolving the morphological evolution of whole landforms, let alone complexes of interacting landforms, presents many challenges. Applications of reductionist sediment dynamics principles to coastal morphodynamic problems are becoming ever more sophisticated (Roelvink and Reniers 2012; van Rijn et al. 2013) and, 
Pre-print: French JR, Burningham H, Thornhill G, Nicholls RJ (2016) Integrating estuarine, coastal and inner shelf sediment systems in a common conceptual framework as a basis for participatory shoreline management. In: Meadows M, Lin J-C (eds.) Geomorphology and society. Springer (in press).

with advances in computing power, simulation over decades and even centuries is feasible for certain environments (e.g. nearshore bars (Ruggiero et al. 2009); tidal basins (Dastgheib et al. 2008) and estuaries (Hibma et al. 2004; van der Wegen and Roelvink 2008). Computational cost still limits the extent to which rigorous calibration and sensitivity analysis are possible, however, and long-term morphological change predicted in this way is typically very sensitive to initial conditions that can usually only be approximated and also to simplifications in the external hydrodynamic forcings (Walstra et al. 2013). An alternative strand of modelling effort embraces more synthesist approaches that are explicitly designed to resolve those aspects of coastal behaviour that emerge naturally at a mesoscale measured in decades to centuries and tens to hundreds of kilometres (Murray et al, 2008; French et al. 2015b). These range from highly aggregated aspatial models that capture selected aspects of mesoscale coastal and estuarine morphodyamics (e.g. Stive et al. 1998; Kragtwijk et al. 2004) to more mechanistic spatially distributed models (e.g. Walkden and Hall 2011).

Irrespective of the quantitative modelling approach adopted, generic principles need to be translated into models that take account of the place-specific contexts in which contemporary processes interact with antecedent geology, sea level history, historical morphology and engineering interventions, and landform dynamics are forced by tidal, wave and sediment supply boundary conditions at broader scales. This requires robust conceptual frameworks for the formalisation of existing knowledge; formulation of relevant scientific questions and management issues; development and implementation of predictive models; and, not least, meaningful engagement with stakeholders. Despite undoubted progress with the development of mesoscale coastal behaviour models (e.g. Walkden and Hall; 2011; Castedo et al. 2012) our conceptualisations have not evolved at a similar pace to support a geomorphologically-informed assessment of erosion and flood risk over the $21^{\text {st }}$ century and beyond (Nicholls et al. 2012). In particular, a reliance on littoral cells as an organising framework makes it difficult to conceptualise the complex web of interactions between the sediment systems of estuaries, open coasts and the inner shelf.

In this chapter, we show how the recently developed Coastal and Estuarine System Mapping (CESM) approach of French et al. (2016a) provides a basis for integrating open coast, estuaries and the inner shelf in a single conceptual framework. CESM captures the configuration of the sediment system, with all its human constraints, at time and space scales relevant to management. It also identifies locations where there is potential for step-changes in configuration, for example due to the breakdown of a spit or breakdown of a barrier. Finally, CESM encourages a more participatory approach to shoreline management by formalising disparate sources of knowledge and drawing stakeholders into the process of defining problems and deploying model-based scientific understanding to find solutions to them.

\section{Integrating our understanding of coastal sediment systems}

Under the shoreline management paradigm that has prevailed in many countries (Leafe et al. 1998; Hunt et al. 2011; Mulder et al. 2011; Nicholls et al. 2013), open coasts have hitherto been treated separately from estuaries. This division of effort has much to do with administrative boundaries and differences in the state agencies responsible for dealing with erosion (more prevalent along open coast) and flood risk (concentrated in estuaries). While such geohazards do present different sets of problems, a divergent approach to their management has led to a 
Pre-print: French JR, Burningham H, Thornhill G, Nicholls RJ (2016) Integrating estuarine, coastal and inner shelf sediment systems in a common conceptual framework as a basis for participatory shoreline management. In: Meadows M, Lin J-C (eds.) Geomorphology and society. Springer (in press).

lack of appreciation of the nature, extent and significance of the sedimentary and morphodynamic interactions between estuaries and the open coast, and indeed the wider shelf.

The need for a more integrative perspective has become more pressing as the strategic application and evaluation of management and engineering options has evolved to address the broader time and space scales at which progressive shifts in shoreline position occur in response to climate change and sea-level rise (French and Burningham 2013). A key area of concern is the fact that littoral cells (Figure 1a) primarily reflect short-range transfers of 'beach-grade' sediment and are not well suited to resolving broader scale linkages between estuarine, coastal and offshore systems (Cooper and Pontee 2006). This limitation is especially apparent where long-range coastal shelf suspended sediment transport fluxes drive morphological change in estuaries (e.g. Kirby 1987; Dyer and Moffat 1998; Keen and Slingerland 2006). Cooper and Pontee (2006) also highlight concerns over the criteria used to delimit littoral cells, and the stability of cell boundaries, especially under significant changes in wave climate or sediment supply. In the UK, these issues were tackled in the FutureCoast project (Burgess et al. 2002), which embedded littoral cells within a spatial hierarchy of geomorphological units (effectively individual landforms), shoreline behaviour units (sub-systems, such as embayments and estuaries) and regional coastal behaviour systems. Applied to the entire open coast of England and Wales, the FutureCoast methodology allowed identification of the scale and nature of the linkages that govern coastal morphological change at the decadal to century timescale and underpinned a second generation of SMPs (Burgess et al. 2004; Hunt et al. 2011). 
Pre-print: French JR, Burningham H, Thornhill G, Nicholls RJ (2016) Integrating estuarine, coastal and inner shelf sediment systems in a common conceptual framework as a basis for participatory shoreline management. In: Meadows M, Lin J-C (eds.) Geomorphology and society. Springer (in press).

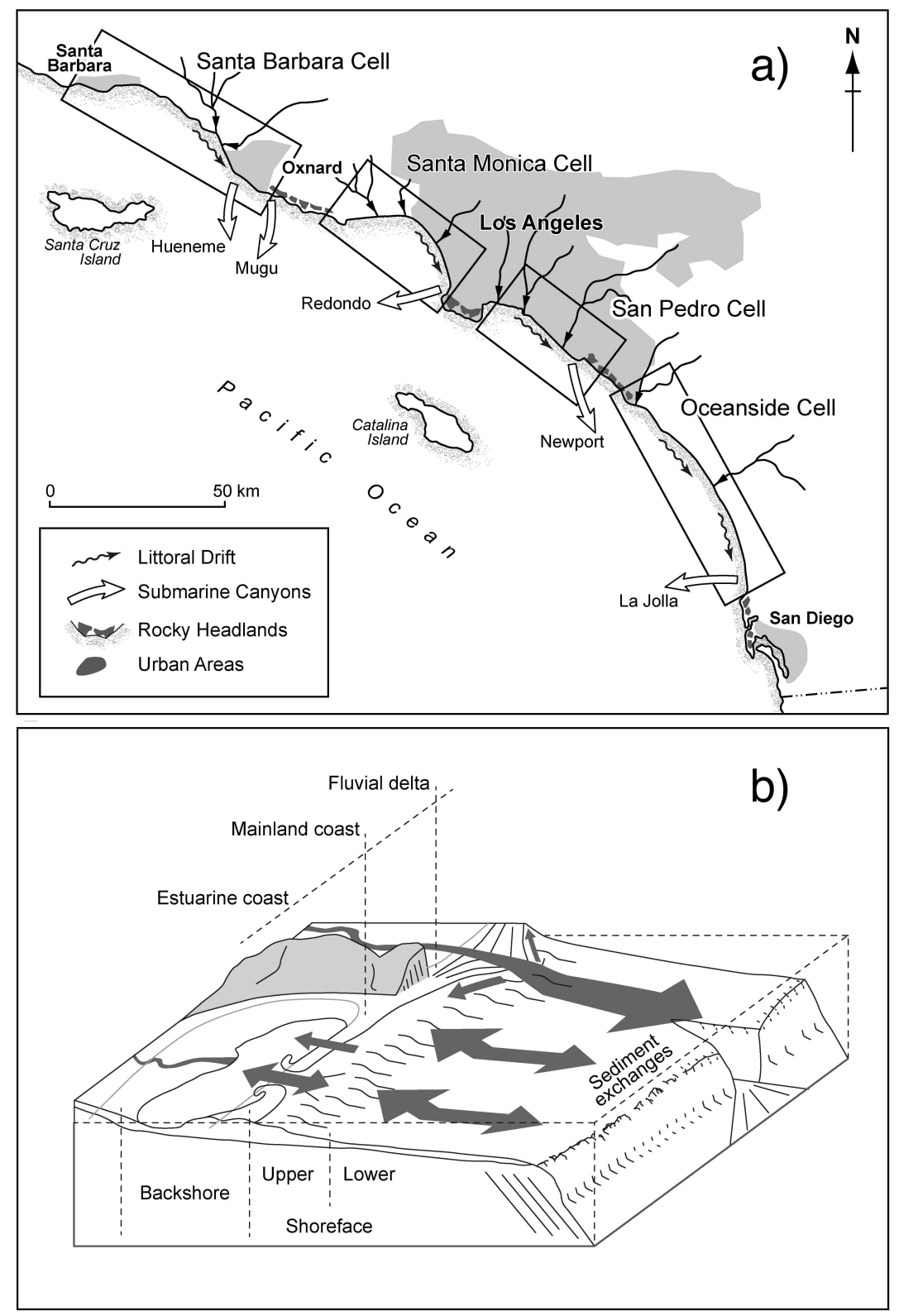

Fig. 1. a) coastal, or littoral, cell concept (after Inman and Frautschy, 1966); b) visualization of coastal tracts (after Cowell et al. 2003).

The concept of the 'coastal tract' developed by Cowell et al. (2003) provides an alternative, though complementary, perspective on coastal morphodynamics at scales directly relevant to shoreline management. Identification of sediment-sharing tracts (Figure $1 \mathrm{~b}$ ) is motivated by the observation that many of the most pressing management issues arise not from the short-term variability that often dominates the observational record but from progressive trends. Accordingly, the tract concept is formulated around a temporal hierarchy in which landforms and complexes of landforms evolve under lower order geological constraints 
Pre-print: French JR, Burningham H, Thornhill G, Nicholls RJ (2016) Integrating estuarine, coastal and inner shelf sediment systems in a common conceptual framework as a basis for participatory shoreline management. In: Meadows M, Lin J-C (eds.) Geomorphology and society. Springer (in press).

(Holocene/Quaternary scale) while subject also to the residual effects, accumulated over larger time scales, of unresolved fine-scale processes. At the same time, successful treatment of coastal tracts requires an expanded spatial scope that includes exchanges of sediment with the lower shoreface as well as interactions between open coast and backbarrier lagoonal and estuarine environments. As French et al. (2016b) observe, contrary to the generally assumed correlation of time and space scales, coupled estuary - coast - inner shelf behaviour is driven by sediment exchanges at multiple nested spatial scales (see also, Figure 2). These are primarily related to distinct sediment size fractions (Keen and Slingerland, 2006; van der Kreeke and Hibma, 2005), as well as to different sets of anthropogenic natural forcing factors (Fenster and Dolan, 1993; Hapke et al., 2013). Beach morphological change tends to occur in response to relatively local sand and gravel transport dynamics, often fed by proximal sea cliff or fluvial sources (e.g. van Lancker et al. 2004; Komar, 2010). In contrast, cohesive sediments from fluvial or coastal cliff sources can sustain estuarine sedimentation hundreds of kilometres from the sources (McCave, 1987; Dronkers et al. 1990; Gerritsen et al. 2000).



Fig. 2. Schematization of temporal and spatial scales of coastal behaviour (based on Cowell and Thom 1994), highlighting a decadal to centennial management mesoscale at which grainsize-dependent sediment system pathways nest at multiple spatial scales. Mesoscale coastal configuration also reflects residual effects (accumulated over larger time scales) of short-term storms, which can effect state changes, for example, by breaching of barriers.

In addition to sediment sharing between coupled landforms and complexes of landforms, other kinds of interaction also influence coastal behaviour. Shelf bank systems (e.g. MacDonald and O'Connor 1994; Park and Wells 2005; Hequette et al. 2008; Hequette and Aernouts 2010) and submarine channels (Browder and McNinch 2006) can both play a role in modifying coastal wave climate, either by reducing wave energy at the shoreline or else focusing it. These systems 
Pre-print: French JR, Burningham H, Thornhill G, Nicholls RJ (2016) Integrating estuarine, coastal and inner shelf sediment systems in a common conceptual framework as a basis for participatory shoreline management. In: Meadows M, Lin J-C (eds.) Geomorphology and society. Springer (in press).

are often morphologically active but may still have little direct sediment exchange with contemporary coastal systems (Antia 1996).

\section{A spatial ontology of estuary - coast - inner shelf sediment system interactions}

As a first step towards articulating the vision outlined above, French et al. (2016a) present an idealised spatial ontology for coupled estuary-coast-inner shelf sediment systems. The term ontology refers to a formal specification of a conceptualisation (Gruber 1992), although this is interpreted rather loosely here to refer to a hierarchical classification of components and a set of permitted interactions between them. As outlined in Figure 3, this scheme reflects certain aspects of the coastal tract concept (Cowell et al. 2003) in its hierarchy of morphologically-active sediment-sharing landforms and landform complexes. These are embedded within the geological context of a shoreface that can be considered time-invariant at decadal to centennial timescales. In contrast to the primarily temporal tract hierarchy (Cowell et al. 2003), our scheme emphasises spatial nesting of discrete landform components within landform complexes, and explicitly represents varied human interventions and the way in which these constrain morphological change. Landform complexes, in turn, are embedded within coastal behaviour systems at a broad regional scale; this parallels the thinking behind the FutureCoast work (Burgess et al. 2002).

\subsection{Landform complexes}

Classification invariably involves a trade-off between the desire to simplify and the need to resolve significant diversity. Several attempts have been made to reduce the wide variation in estuary morphology and origin to a small set of sub-types. In a New Zealand context, Hume and Herdendorf (1988) identified five major modes of estuarine basin formation, within which 16 estuary sub-types occur. A more elaborate scheme incorporating several distinct levels of controlling factors was presented by Hume et al. (2007). Davidson and Buck's (1997) classification of British estuaries into eight types was rationalised to seven generic types by ABPmer (2008), based on the consideration of 163 estuaries around the entire UK coast. This scheme (Figure 4a) was adopted for CESM by French et al. (2016a) on the basis that its simplicity reduces the potential for variation between maps produced by different 'experts' due to subjective classificatory judgements.

For open coasts, a similarly minimal classification is feasible. That shown in Figure $4 \mathrm{~b}$ recognises mainland coast (cf. Cowell et al. 2003), and augments this with headlands and bays for coasts that exhibit more obvious geological control. Cuspate forelands and spits are locally prominent around the British coast and some are large enough to be afforded the status of a landform complex (Plater et al. 2009), as are a variety of barrier features (Bray, 1997; Funnell et al. 2000). For application in other geographical contexts, additional complexes would clearly be required (most obviously deltas, which do not feature on the contemporary British coast).

Individual landforms are less abundant over much of the inner shelf, although the interaction between drowned palaeo-landscapes of the last glacial (Harris et al. 2013) and modern shoreline dynamics is attracting increasing attention (McNinch 2004). Many shallow shelf seas are characterized by bank systems that differ in morphology, organization and origin (e.g. Swift and Field 1975; Belderson 1986; Hequette and Aernouts 2010). In a UK context, sand bank complexes (and isolated features) are common in the North Sea (Caston 1972; Burningham and 
Pre-print: French JR, Burningham H, Thornhill G, Nicholls RJ (2016) Integrating estuarine, coastal and inner shelf sediment systems in a common conceptual framework as a basis for participatory shoreline management. In: Meadows M, Lin J-C (eds.) Geomorphology and society. Springer (in press).

French 2011), where they are known to influence contemporary shoreline behaviour by modifying coastal wave climate (Dolphin et al. 2007) and via their role in sediment pathways (Robinson 1966; Chang and Evans 1992). Figure 4c distils a detailed analysis by Dyer and Huntley (1999) into three distinct types. Shelf bank systems may or may not be morphologically active and, at decadal to centennial scales, chiefly act to modify coastal wave climate (e.g. Chini et al. 2010). They are also associated with tidal interactions controlling broader bedload sediment transport pathways and residual currents influencing fine sediment transport (e.g. Dyer and Moffatt 1998). Linear bank systems are associated with larger meso- to macro-tidal estuaries (e.g. Burningham and French 2011). Nearshore bank systems include the various forms of headland-attached ridge (Caston 1972; Schmidt et al. 2007).



high-order interannual and sub-annual variability

Fig. 3. Spatial ontology of coupled estuary-coast-inner shelf geomorphic systems (modified from French et al. (2016a).

\subsection{Landforms}

Estuarine, open coastal, and inner shelf complexes are aggregations of individual landforms (Table 1). The same landform type may occur within more than one type of landform complex (e.g. tidal flat, which can occur in both open coast and estuarine settings). Other landform types such as spits and ebb tidal deltas occur at the interface between estuary and open coast and, as such, could be considered to be part of either complex. Spits are a special case in that larger examples can be mapped as a complex (including landforms such as beach, beach ridge, dune and saltmarsh) while minor features can be considered to be landforms embedded within a larger complex. At decadal to centennial scales, hinterland imposes an essentially static boundary condition control. Terrain that rises well above current and projected future tide and surge elevations and would be expected to show a largely erosional response to sea-level rise is 
Pre-print: French JR, Burningham H, Thornhill G, Nicholls RJ (2016) Integrating estuarine, coastal and inner shelf sediment systems in a common conceptual framework as a basis for participatory shoreline management. In: Meadows M, Lin J-C (eds.) Geomorphology and society. Springer (in press).

referred to as high ground. Low ground is identified as being more susceptible to inundation, although erosion can also lead to increased flood risk such that the two hazards are not independent. Reclaimed areas have been converted from former subtidal or intertidal landforms, and are protected from tidal inundation by fixed defences.

a)

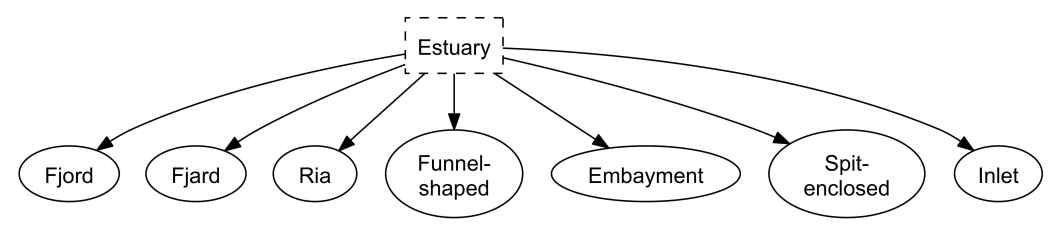

b)
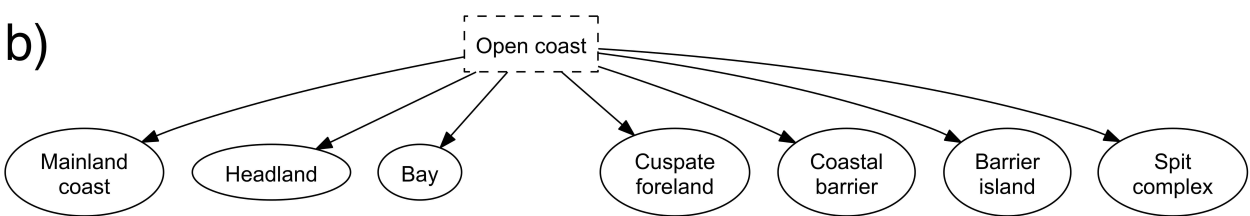

c)



Fig. 4. Classification of UK (a) estuary, (b) coastal and (c) inner shelf landform complexes (modified from French et al. (2016a).

Coastal, estuarine and shelf sediment systems also include reservoirs of sediment that can be locally important in mediating landform behaviour. The inner shelf is typically veneered by patches of sediment, some of which are inactive under present sea level, wave climate and tidal regime, and some of which exchange sediment with coastal or estuarine environments. Seabed stores can be classified according to grain size, and their interaction with the contemporary sediment system elucidated by consideration of shelf sediment pathways (e.g. Poulos and Ballay 2010), possibly augmented by sediment transport modelling (Barnard 2013; Brown et al., 2015).

\subsection{Human interventions}

As noted above, present-day coastal behaviour is strongly conditioned by a multitude of human interventions. The effects of coastal protection works are evident locally (Runyan and Griggs 2003; Basco 2006), regionally (Clayton 1989; Dawson et al. 2009; Brown et al. 2011) and even nationally (van Koningsfeld et al. 2008; Hapke et al. 2013). The most obvious interventions are structural, installed with the aim of preventing erosion, reducing flooding or facilitating reclamation. Engineering practice has evolved to incorporate varied local experiences and requirements, and this is reflected in a diverse terminology for structures that perform the same 
Pre-print: French JR, Burningham H, Thornhill G, Nicholls RJ (2016) Integrating estuarine, coastal and inner shelf sediment systems in a common conceptual framework as a basis for participatory shoreline management. In: Meadows M, Lin J-C (eds.) Geomorphology and society. Springer (in press).

function. It is therefore useful to adopt a highly generic classification of intervention types according to the function that they perform. In the scheme summarised in Table 2, most interventions have the effect of arresting movement, for example through limiting erosional retreat or channel migration. Some, such as groyne fields, represent a direct intervention to retain or restore a sediment store and any associated littoral drift pathway. Non-structural interventions in coastal and estuarine sediment systems are also common, not only through dredging and aggregate extraction (Hitchcock and Bell 2004) but also through 'softer' and more adaptive approaches to coastal management including beneficial reworking of sediment (including various forms of nourishment or recharge) to restore known deficits and enhance the resilience of degraded environments (Khalil et al. 2010; van Slobbe et al. 2013).

Table 1. Landform components common to open coastal, estuarine and inner-shelf complexes. These comprise morphologically active landforms, as well as sediment reservoirs, and hinterlands that are not considered to evolve their morphology at timescales of decades to centuries. Note that this set has been devised for application in a UK context; other settings may involve landforms not represented here.

\begin{tabular}{llll}
\hline Landform & & Hinterland & Sediment store \\
\hline Cliff & Inlet channel & High ground & Seabed gravel \\
Shore platform & Ebb delta & Low ground & Seabed sand \\
Beach & Flood delta & Reclaimed & Seabed mud \\
Beach ridge & Bank & & Suspended mud \\
Tombolo & Channel & \\
Dune & Tidal flat & \\
Spit & Saltmarsh & & \\
Rock outcrop & Brackish marsh & & \\
Lagoon & River & & \\
\hline
\end{tabular}

\subsection{Interactions}

The ontology described above includes about 60 components, distributed over four hierarchy levels. From a functional perspective, components influence each other through a complex web of interactions. Interactions in the broadest sense refer to any cause-effect relation between components. For example, a jetty exerts an effect on an inlet channel, stabilising its location and also influencing its cross-sectional characteristics. Some components (e.g. beach, inlet channel, channel) are far more connected than others (including the less common landforms and structural interventions). Some interactions are bidirectional, such as the interplay between a seawall and a beach (Basco 2006). A sub-set of the interaction network involves transfers of mass and these sediment pathways define the sediment budget. Some of the linkages may be unidirectional, for example where sequential beach units define a littoral drift system. Others may represent more complex causality: a cliff may source sediment to a fronting beach (mass transfer) and the beach may influence the cliff (via an influence whereby beach morphology feeds back into the cliff recession rate; Walkden and Hall 2011). 
Pre-print: French JR, Burningham H, Thornhill G, Nicholls RJ (2016) Integrating estuarine, coastal and inner shelf sediment systems in a common conceptual framework as a basis for participatory shoreline management. In: Meadows M, Lin J-C (eds.) Geomorphology and society. Springer (in press).

Table 2. Minimal classification of generic structural and non-structural interventions in estuary, coast and inner shelf sediment systems, with their indicative purpose.

\begin{tabular}{|c|c|c|c|}
\hline Structural & (indicative purpose) & Non-structural & (indicative purpose) \\
\hline Seawall & Erosion protection & Dredging & Navigation; mining \\
\hline Revetment & Erosion protection & Dredge disposal & Spoil disposal \\
\hline Bulkhead & Erosion protection & Sediment recharge & $\begin{array}{l}\text { Restoration of sediment } \\
\text { deficit (beach, intertidal) }\end{array}$ \\
\hline Embankment & Flood protection & Sediment bypassing & $\begin{array}{l}\text { Continuity of sediment } \\
\text { pathway; navigation }\end{array}$ \\
\hline Barrage & Flood protection & Sediment recycling & $\begin{array}{l}\text { Resilience (beach } \\
\text { profiling); navigation }\end{array}$ \\
\hline Breakwater & Wave energy reduction & & \\
\hline Detached breakwater(s) & Wave energy reduction & & \\
\hline Groyne(s) & Sediment retention & & \\
\hline Training wall & $\begin{array}{l}\text { Channel stabilisation / } \\
\text { navigation }\end{array}$ & & \\
\hline Jetty & Varied & & \\
\hline Outfall & Drainage / dispersal & & \\
\hline Quay & Navigation/trade & & \\
\hline Dock & Navigation/trade & & \\
\hline Weir & $\begin{array}{l}\text { Regulation of river } \\
\text { gradient and/or tidal } \\
\text { limit }\end{array}$ & & \\
\hline
\end{tabular}

Consistency in the representation of system interactions is clearly important and can be achieved through careful tabulation of permitted interactions, their nature and directionality, and a supporting logic backed by references to the scientific literature. Table 3 presents an illustrative portion of an interaction matrix for selected system components. Three types of interaction are possible: (1) None - paired components exert no direct influence on each other; (2) Influence, where there is a process interaction, such as wave sheltering, but no direct sediment exchange; and (3) Sediment pathway - a direct exchange of sediment between components. The entire set of system components can be treated in this way, such that the ontology goes beyond a simple classification to specify which landforms can be assembled into complexes, the manner in which they interact, and the effect of various human interventions. Whilst local circumstances may generate situations that require special provision, a priori specification of system interaction types is essential to ensure consistency when system mapping is applied in practice.

\section{Coastal and Estuarine System Mapping (CESM)}

The CESM approach (French et al. 2015a) provides a means of capturing the configuration of the key morphological components, human interventions, and the sediment and other influence pathways that connect them. Given the emphasis on system behaviour at decadal to centennial scales, seasonal and interannual variability is excluded in favour of more persistent interactions. The result is a time-averaged view of system configuration as conditioned by present processes and human constraints. Behavioural dynamics are not resolved, although in certain situations it 
Pre-print: French JR, Burningham H, Thornhill G, Nicholls RJ (2016) Integrating estuarine, coastal and inner shelf sediment systems in a common conceptual framework as a basis for participatory shoreline management. In: Meadows M, Lin J-C (eds.) Geomorphology and society. Springer (in press).

is possible to envisage event-driven changes in gross configuration, such as the breakdown of a barrier to create to create a new tidal inlet. Configurational state changes of this nature are considered further below.

Table 3. Illustrative paired examples of interaction rules for landforms and interventions.

\begin{tabular}{|c|c|c|c|}
\hline From & To & Interaction & Logic (literature source) \\
\hline Cliff & Beach & $\begin{array}{l}\text { Sediment pathway } \\
\text { (sand, gravel) }\end{array}$ & 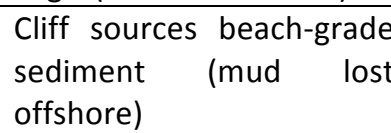 \\
\hline Beach & Cliff & Influence & $\begin{array}{l}\text { Presence and morphology } \\
\text { of beach feeds back into } \\
\text { cliff recession rate (e.g. } \\
\text { Walkden and Hall 2011) }\end{array}$ \\
\hline ....... & $\ldots \ldots$ & $\ldots \ldots$ & $\ldots \ldots$ \\
\hline Seawall & Beach & Influence & $\begin{array}{l}\text { Presence of seawall may } \\
\text { cause lowering of beach } \\
\text { (e.g. Basco 2006) }\end{array}$ \\
\hline Beach & Seawall & Influence & $\begin{array}{l}\text { Beach protects toe of } \\
\text { seawall and reduces wave } \\
\text { energy on face }\end{array}$ \\
\hline ....... & ....... & ....... & ....... \\
\hline Jetty & Inlet channel & Influence & $\begin{array}{l}\text { Jetty exerts stabilising } \\
\text { influence on channel } \\
\text { position and constrain } \\
\text { width adjustment }\end{array}$ \\
\hline Inlet channel & Jetty & none & $\begin{array}{l}\text { No direct causal relation in } \\
\text { this direction }\end{array}$ \\
\hline
\end{tabular}

The workflow for CESM (Figure 5) commences with 'specification' of the problem at hand, for which a formal statement of the application is required. A suitable time-averaging period over which to characterise the configuration of the coastal sediment system is chosen at this stage. For strategic management problems, including those relating to climate change impacts, relevant timescales are usually decades to centuries (French et al. 2015b). The level of spatial detail required, as well as the geographical scope, are also determined at this stage. The latter might vary from regional mapping to guide the preparation of a shoreline management plan to mapping of individual intertidal flat, saltmarsh and reclaimed flood compartments to provide context for a specific flood defence management scheme. The next step is to determine the most effective route to formalising the current state of understanding. For well documented and/or understood systems, a lone expert or small team of experts may be able to achieve a relatively uncontentious synthesis of existing knowledge. Where a system is less well understood, CESM provides a starting point for the development of a conceptual model and a larger team might be required to achieve a consensus. This might be a joint effort or else achieved through rival efforts that highlight areas of divergent opinion. Finally, background knowledge (published papers, reports etc.) and plain data (aerial images, bathymetry, historical shoreline change analyses etc.) are assembled to support subsequent stages of the mapping process. 
Pre-print: French JR, Burningham H, Thornhill G, Nicholls RJ (2016) Integrating estuarine, coastal and inner shelf sediment systems in a common conceptual framework as a basis for participatory shoreline management. In: Meadows M, Lin J-C (eds.) Geomorphology and society. Springer (in press).

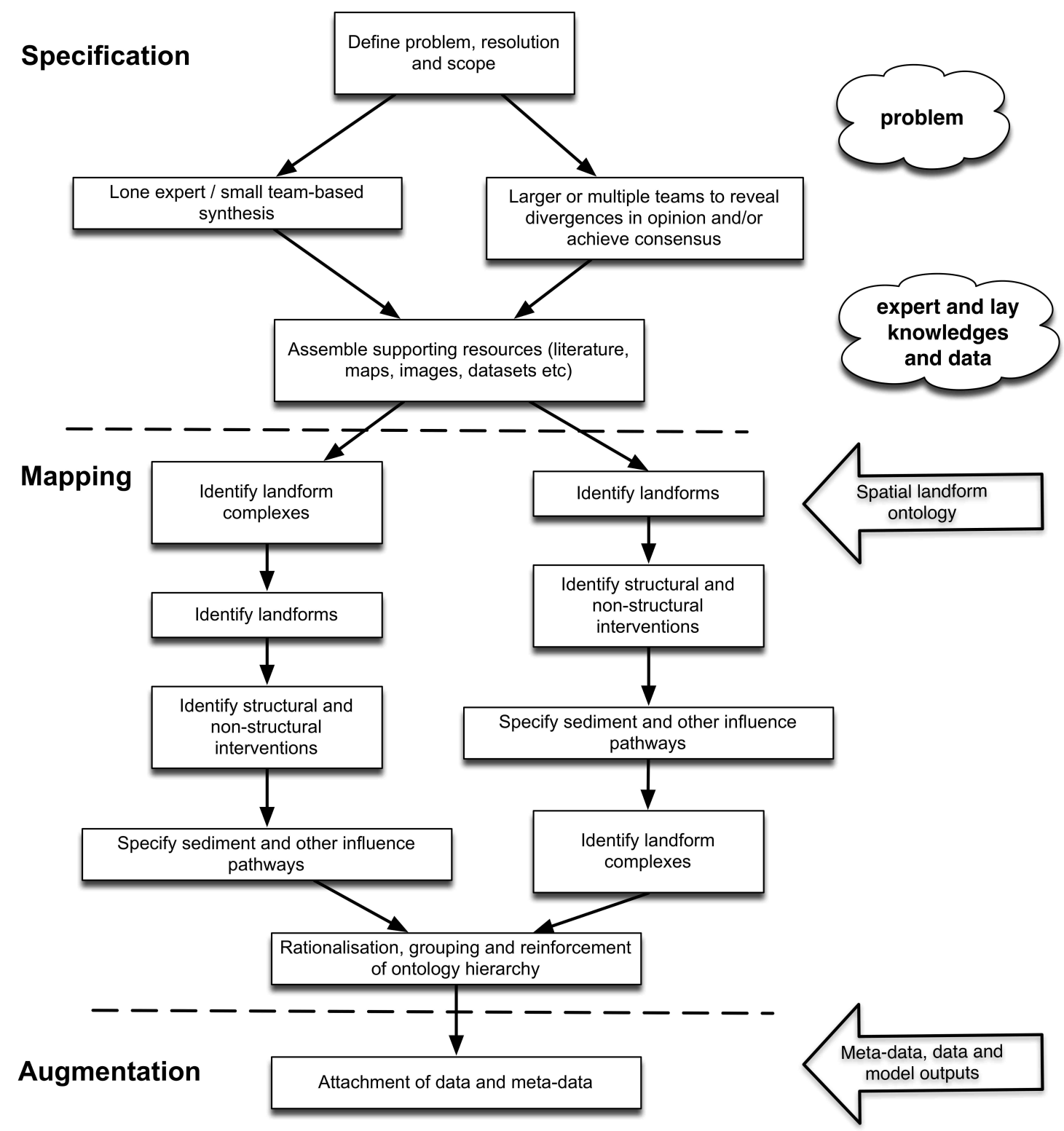

Fig. 5. Workflow for Coastal and Estuarine System Mapping (after French et al., 2015a).

Mapping may then follow a 'top down' route, in which landform complexes are identified first and then populated with landform detail, or a 'bottom up' route whereby landforms and interventions are mapped in detail and then organised into broader-scale complexes. Both require a robust protocol for the identification of discrete system components and the interactions between them.

Figure 6 illustrates this for an example case of the interactions between a small spit-enclosed estuary and a sandy open coastal bay bounded by headlands formed in more resistant geology. 
Pre-print: French JR, Burningham H, Thornhill G, Nicholls RJ (2016) Integrating estuarine, coastal and inner shelf sediment systems in a common conceptual framework as a basis for participatory shoreline management. In: Meadows M, Lin J-C (eds.) Geomorphology and society. Springer (in press).

Mapping of the open coast proceeds by identifying distinct hinterland - backshore - nearshore sequences and any local constraints due to structures or known non-structural interventions (e.g. beach nourishment or sediment bypassing programmes). This is similar to the approach taken by Hanson et al. (2010) in their scheme for mapping barrier and non-barrier coasts based on sequential transitions in cross-shore profile type and a set of prescribed landform elements. Figure 7a illustrates a portion of the open coast, showing backshore to hinterland sequences of landforms together with human interventions (including a minor jetty and extensive groynes, bulkhead and embankments). Alongshore intervals are chosen to segment the coast into units that can be considered to function more-or-less as an integrated whole. Interaction pathways are then added, with the directionality of the sediment pathways indicated, and distinction made between these and 'influence only' interactions that are not part of the sediment system.

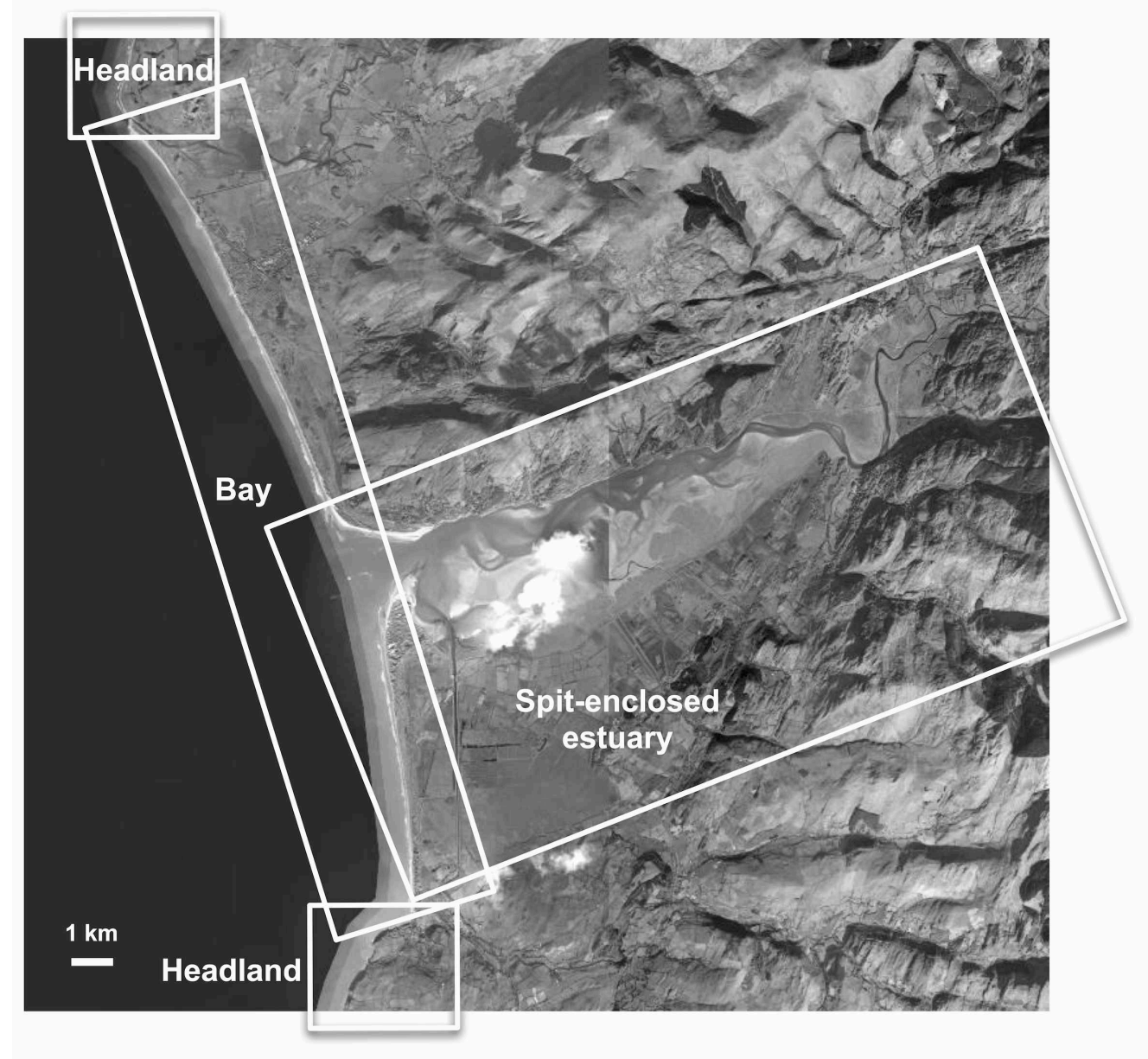

Fig. 6. Illustrative composition of open coast and estuary landform complexes. 
Pre-print: French JR, Burningham H, Thornhill G, Nicholls RJ (2016) Integrating estuarine, coastal and inner shelf sediment systems in a common conceptual framework as a basis for participatory shoreline management. In: Meadows M, Lin J-C (eds.) Geomorphology and society. Springer (in press).
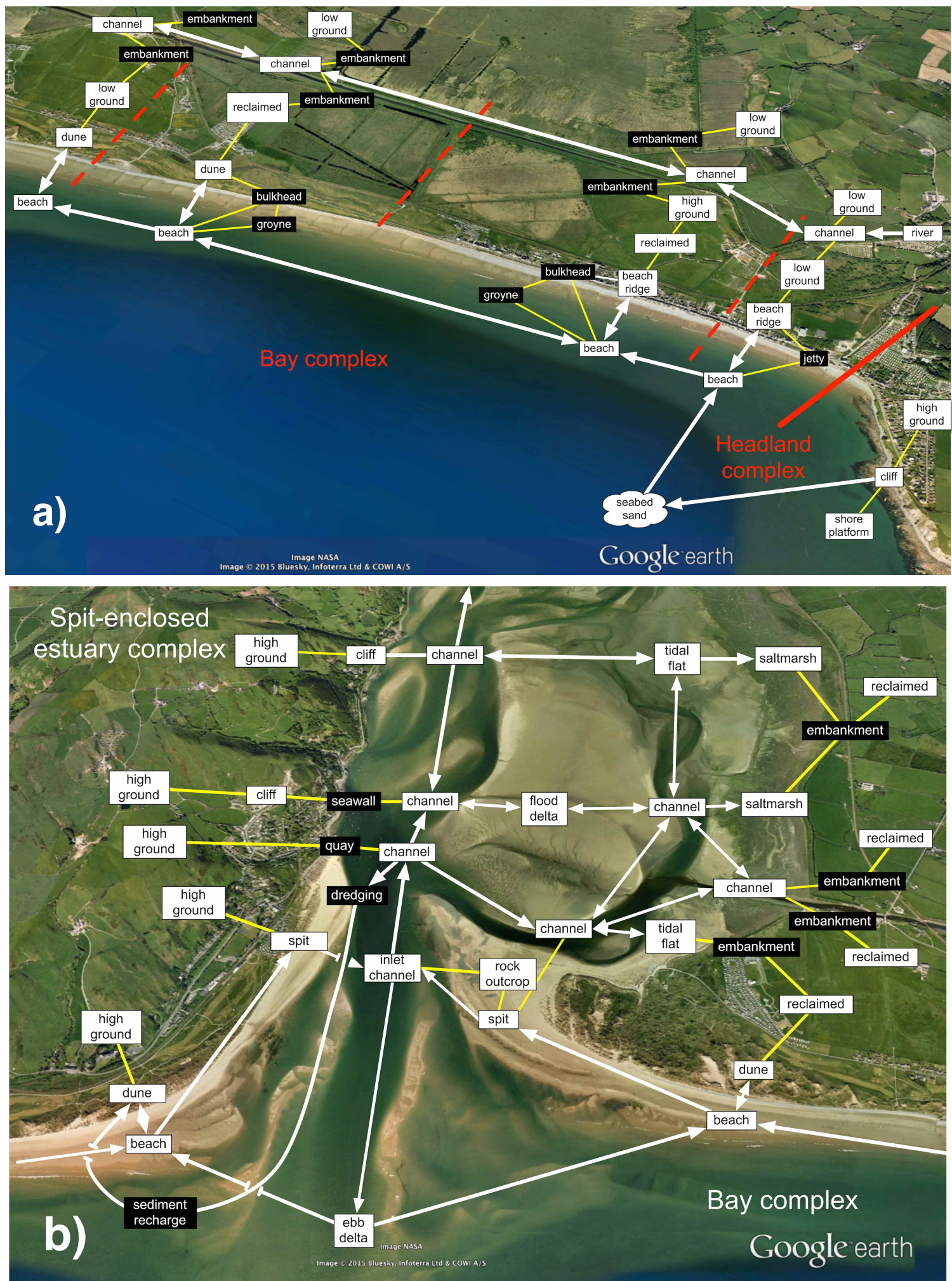

Fig. 7. a) illustrative open coast mapping for a portion of bay complex showing segmentation into distinct cross-shore transitions (demarcated with broken red lines), with directional sediment pathways (white) and 'influence only' interactions (yellow); b) equivalent mapping of outer estuary, showing contrasting intertidal - backshore - hinterland sequences either side of central channel. 
Pre-print: French JR, Burningham H, Thornhill G, Nicholls RJ (2016) Integrating estuarine, coastal and inner shelf sediment systems in a common conceptual framework as a basis for participatory shoreline management. In: Meadows M, Lin J-C (eds.) Geomorphology and society. Springer (in press).

Within the estuary, distinct subtidal - intertidal - hinterland transitions are similarly mapped with reference to the dominant axis of the estuary. This is illustrated for part of the outer estuary in Figure $7 \mathrm{~b}$. This particular spit-enclosed estuary exhibits an asymmetric cross-sectional morphology, with a northern shore (left edge of figure) flanked by high ground and cliffs (partly protected by seawalls) and a southern shore with wide tidal flats, saltmarsh and embankments protecting reclaimed wetlands. The estuary exchanges sand with adjacent beaches via the paired spits, one of which is welded to the northern shore, and the tidal delta sand bodies. Sand dredged from the harbour channel is used to nourish dunes to the north.

Mapping of landform components and interventions connected by various forms of influence effectively represents a system as a network graph. This allows for more quantitative analysis, ranging from simple inventories and interaction probabilities to more sophisticated inferences of overall system behaviour based on network topology (e.g. Phillips 2012). Network graph analyses are sensitive to the way the system is rendered in terms of discrete components (network nodes) and interactions (edges or links). In the case of geomorphological systems, this process involves subjective judgement regarding the demarcation of discrete landforms within continuous landscapes. Moreover, CESM generates multiple instances of individual landforms where these are considered to participate in more than one alongshore or along-estuary segment. Rationalisation of the map topology is therefore needed to merge multiple instances of the same geomorphic feature. Figure 8 illustrates this for the outer estuary. Duplicate landforms and interventions are merged where possible but channels or beaches may be associated with known convergences or divergences in sediment flux, such that their disaggregation into multiple functional components is then justified. Note that, since hinterland is represented as a bounding effect on the active coastal and estuarine system rather than a dynamic landscape component, its labelling is determined from a purely aesthetic perspective.

The workflow in Figure 5 incorporates a final 'augmentation' stage, in which the system map can be annotated to include metadata (e.g. references and active links to relevant research and datasets) as well as data (e.g. digital research documents, images, observational datasets and model outputs). This functionality is facilitated by implementation of CESM a geospatial software environment, as outlined below. 
Pre-print: French JR, Burningham H, Thornhill G, Nicholls RJ (2016) Integrating estuarine, coastal and inner shelf sediment systems in a common conceptual framework as a basis for participatory shoreline management. In: Meadows M, Lin J-C (eds.) Geomorphology and society. Springer (in press).

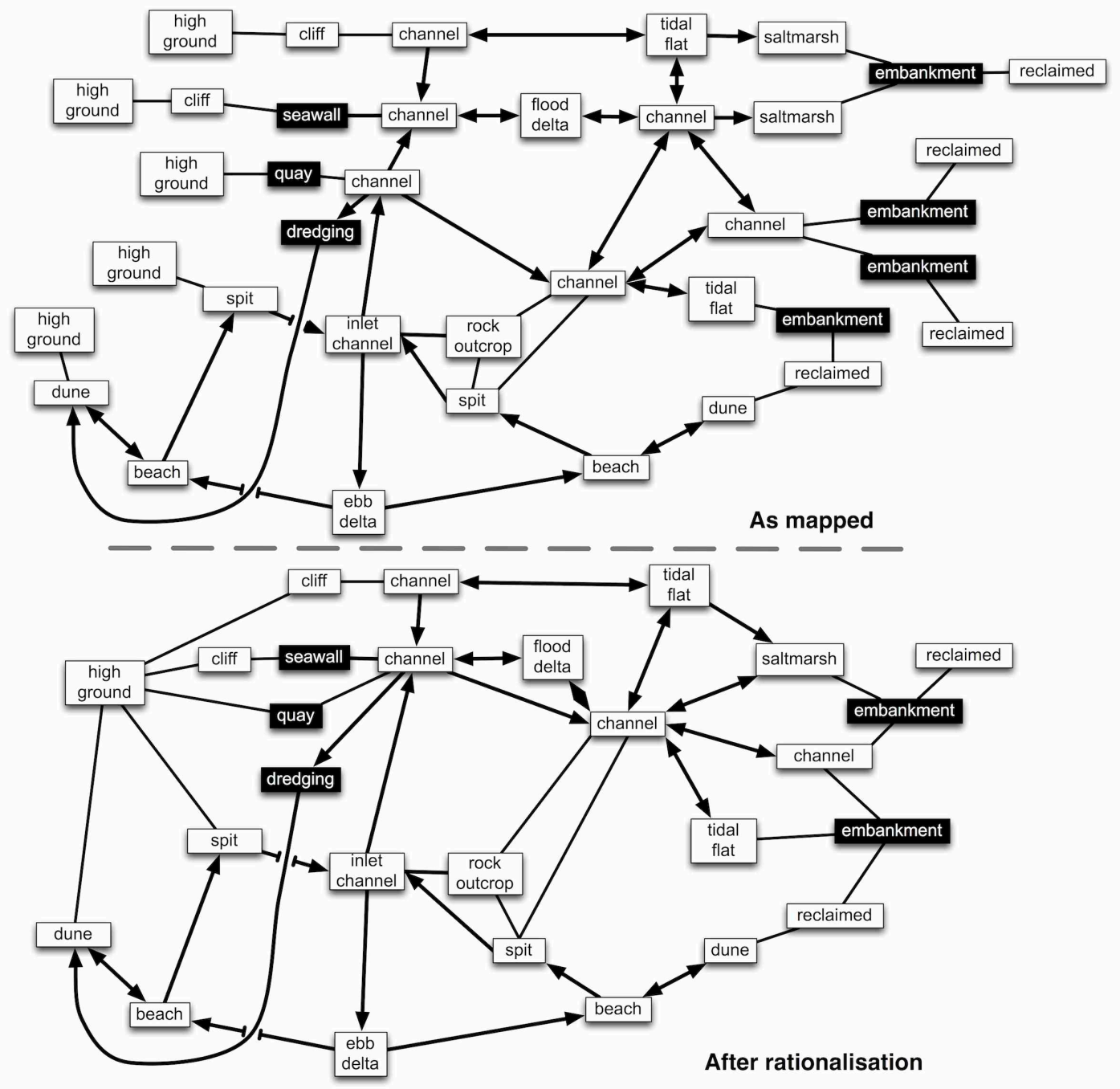

Fig 8. Rationalisation of the outer estuary network graph (Figure 7b) to remove multiple instances of the same component where possible.

\subsection{Implementation of CESM within an open-source GIS framework}

Initial development of the CESM approach (French and Burningham 2009) was undertaken using concept mapping software (CmapTools; Cañas et al. 2005) that lacked the ability to produce georeferenced system maps or to directly utilise geospatial datasets. To address this, French at al. (2015a) developed bespoke CESM software that operates within a Geographical Information System (GIS) framework. The open source QGIS (http://www.qgis.org) was selected as a geospatial platform on account of its support for multiple operating systems and growing user base. The CESM workflow has been implemented as a QGIS plugin (coded in Python) that enables system components to be mapped interactively over one or more QGIS data layers.

System mapping is performed within the QGIS environment with reference to a base layer that defines the projection and co-ordinate system. This base layer may take the form of digital mapping, Web Map Server-based layers (including Google Maps or Bing maps), or digital 
Pre-print: French JR, Burningham H, Thornhill G, Nicholls RJ (2016) Integrating estuarine, coastal and inner shelf sediment systems in a common conceptual framework as a basis for participatory shoreline management. In: Meadows M, Lin J-C (eds.) Geomorphology and society. Springer (in press).

photography. Additional 'helper layers' can be loaded into the GIS to aid the identification of landform types and identify human interventions. Airborne LiDAR raster layers are especially useful, as are digital bathymetric charts and geological maps, and vector databases of flood and coastal defence infrastructure.

A key feature of the QGIS CESM plugin is specification of the ontology in an external file that can be edited as required to suit particular regional situations. Sets of components (landforms, landform complexes, interventions) are read from the ontology and used to populate Graphical User Interface (GUI) palettes. These provide the user with a pre-determined set of system elements and impose constraints on how these can be combined. The user may also interactively define the linkages between components and specify the type and directionality of the connection (influence, sediment transfer). It is also possible to include numerical values for sediment fluxes where these are known quantities. Aggregation of landforms into complexes is also checked against ontology rules. This ensures consistency and helps minimise differences of interpretation where the same region is mapped by different users. Final maps comprise a point layer of components and a line layer of connections and can be saved in the widely used ESRI shape file format.

\subsection{Illustrative application - Suffolk coast, eastern England}

The CESM approach and software are presently being used within the Integrating Coastal Sediment Systems (iCOASST) project (Nicholls et al. 2012) to support the development of new quantitative models of coastal and estuarine morphological change. In iCOASST, system maps provide a means of determining how best to break down a regional coastal behaviour system into a set of complexes of constituent landforms that can be simulated by specific coastal and estuarine models. Identification of discrete landform components, interventions and interactions between them at a sub-complex scale then informs the development of specific model codes. A novel feature of the project is that the model codes being developed are compliant with the OpenMI coupling standard (Harpham et al. 2014). By assembling 'compositions' of models that exchange information at run time, coupled coastal and estuarine behaviour can be simulated at a regional scale.

The Suffolk coast, eastern England, is one of the main iCOASST model validation regions (Nichols et al. 2012). Extending from Lowestoft in the north to Felixstowe in the south, the open coastal length of approximately $77 \mathrm{~km}$ can be broken down into a sequence of open coastal, estuarine and inner shelf landform complexes (Figure 9). The mainland coast largely comprises stretches of cliff-backed sand and gravel beaches (Burningham and French 2015a) interspersed with discrete barrier-enclosed lagoons (Spencer and Brooks, 2012). The cliffed coastline north of the Blyth estuary has a long history of erosion, with recession rates up to $5 \mathrm{myr}^{-1}$ (Brooks and Spencer, 2014; Walkden et al. 2015), but sediments released through this erosion are largely sand and gravel (Burningham and French 2015b). The alongshore continuity of the open coast is punctuated by the inlets of the Blyth, Alde/Ore and Deben estuaries, all of which have extensive, predominantly muddy, intertidal flat and saltmarsh. These estuaries were extensively embanked and reclaimed for agriculture in the 18th and 19th centuries, and many of the defensive embankments are now susceptible to overtopping and breaching under extreme tidal surges (French, 2008). The predominantly muddy sedimentation within these estuaries is sustained by long range fluxes of mud within the coastal waters of the southern North Sea (Dyer and Moffat, 1998; French et al., 2008), presumably originating in cliff to the north in Norfolk and Yorkshire 
Pre-print: French JR, Burningham H, Thornhill G, Nicholls RJ (2016) Integrating estuarine, coastal and inner shelf sediment systems in a common conceptual framework as a basis for participatory shoreline management. In: Meadows M, Lin J-C (eds.) Geomorphology and society. Springer (in press).

given that local cliff retreat contributes virtually no muddy material (Burningham and French 2015b).

Figure 10 illustrates the development of the system map using the QGIS software. The screenshot highlights some of the local interactions between estuary and adjacent coastal in the vicinity of the Alde/Ore estuary inlet and Orfordness. This includes cyclical sediment bypassing via spit growth and breaching and ebb shoal migration (Burningham and French, 2007; Burningham, 2015) that has historically sustained downdrift beaches. This figure also illustrates the use of a LiDAR-derived elevation raster layer, a bathymetry vector layer and Bing aerial imagery to assist the mapping process within the QGIS plugin tool.

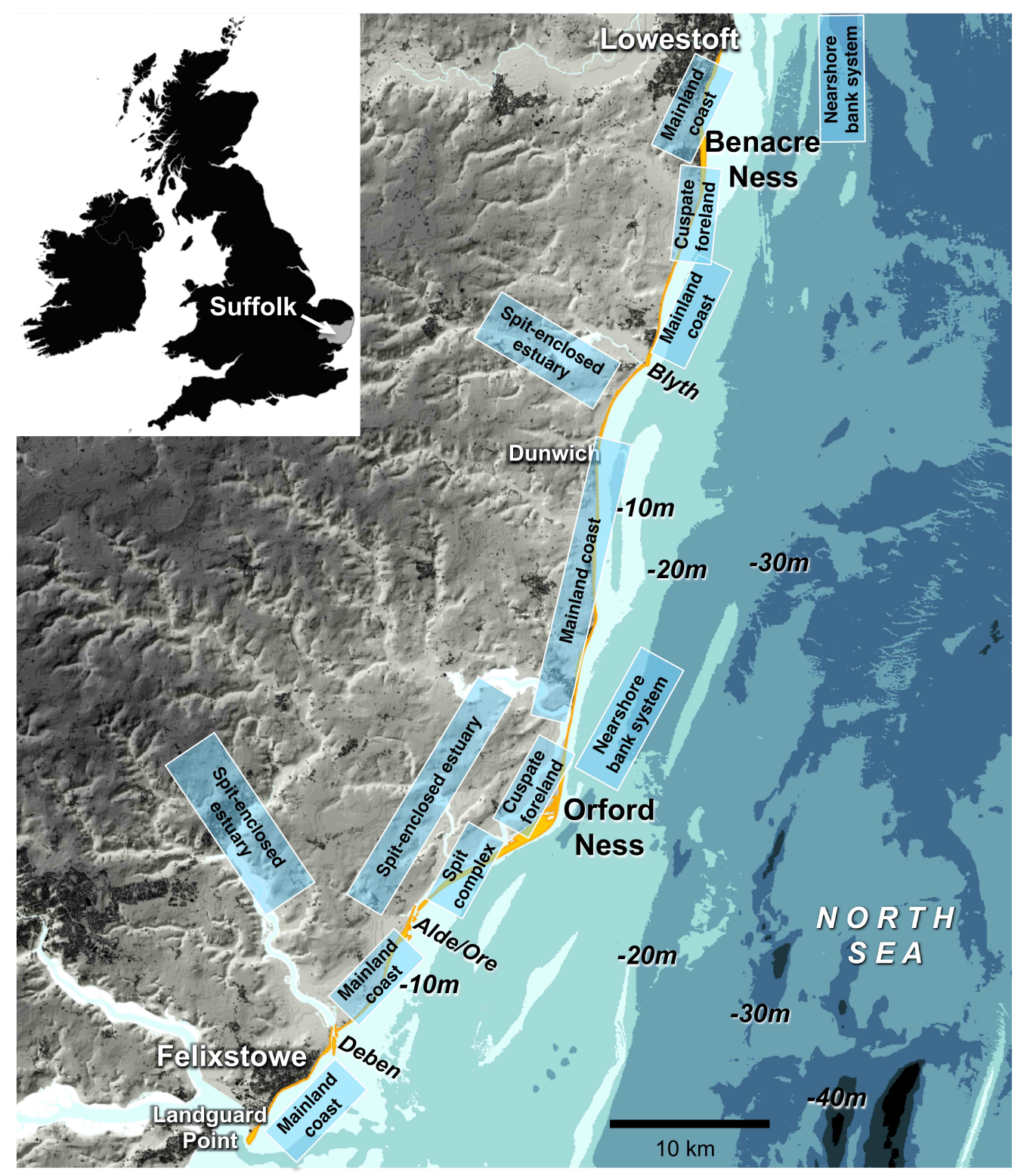

Fig. 9. Division of the Suffolk coastal behaviour system into open coast, estuary and inner shelf landform complexes. 
Pre-print: French JR, Burningham H, Thornhill G, Nicholls RJ (2016) Integrating estuarine, coastal and inner shelf sediment systems in a common conceptual framework as a basis for participatory shoreline management. In: Meadows M, Lin J-C (eds.) Geomorphology and society. Springer (in press).

In its simplest form, the map of components and interactions presents a highly accessible representation of the structure of the coastal and estuarine system. In Figure 10, landforms along the open coast are connected by a littoral sediment transport corridor that is intersected by the estuary inlets. Estuarine landforms are connected to more distant fine sediment sources through channel-open sea suspended sediment transport pathways. As noted earlier, it is also possible to analyse the system map as a network graph. Phillips (2012) explores some quite sophisticated graph-based analyses of geomorphic system structure, but even quite simple visualisations of the occurrence of the different landforms and interactions can be extremely effective as a means of communicating with stakeholders. For example, normalised interaction probability matrices (Figure 11) have generated considerable interest at stakeholder workshops conducted in the iCOASST project. This type of analysis for Suffolk highlights the dominant sediment fluxes within the littoral (beach-beach/beach ridge) and estuarine (channelchannel/saltmarsh) subsystems. The influence matrix also demonstrates the importance of embankments in controlling estuary morphology.

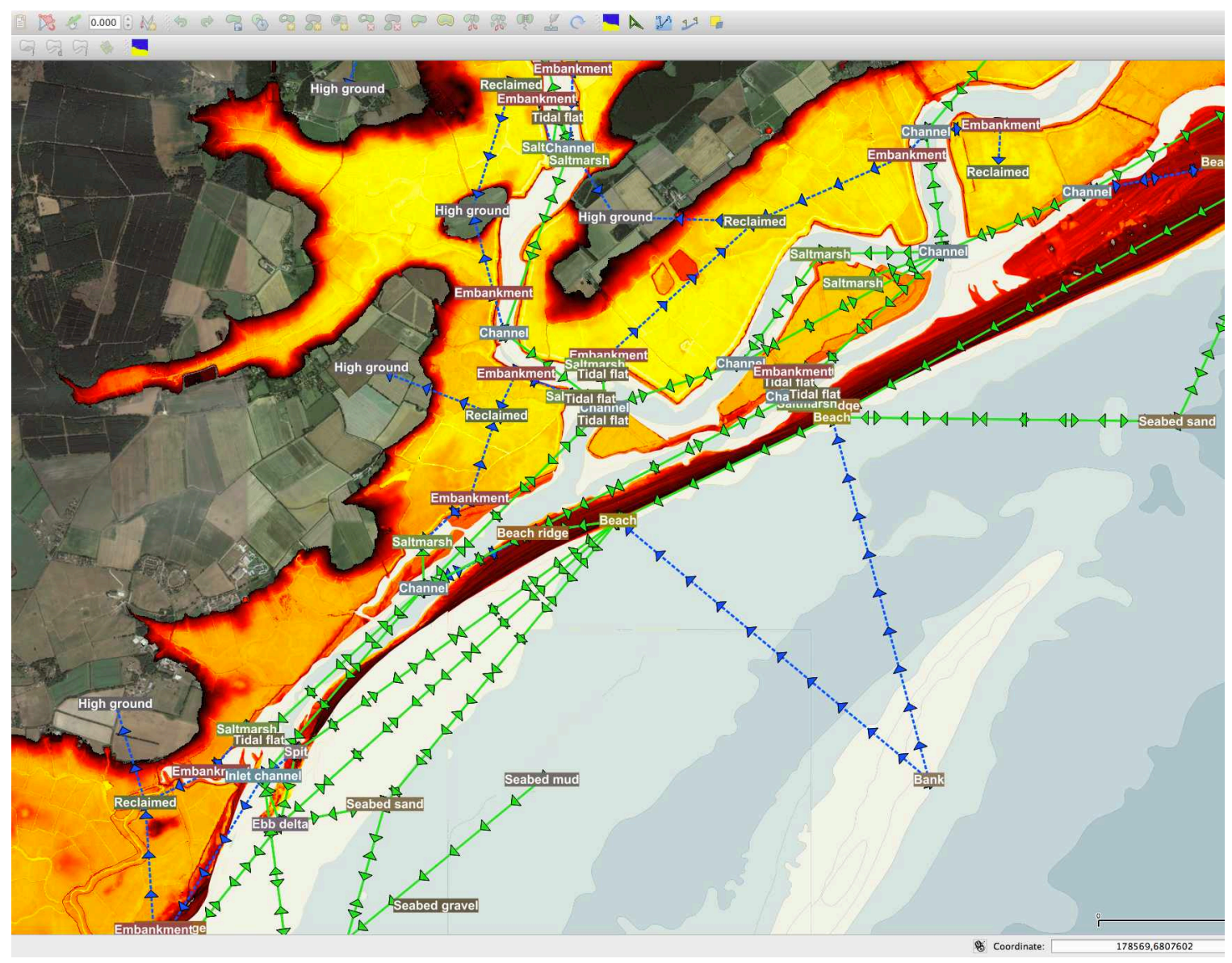

Fig. 10. Illustrative screenshot showing development of system map for region around mouth of the Alde/Ore estuary using CESM QGIS plugin. Terrain shading is a LiDAR DEM overlaid on vertical aerial photography. 
Pre-print: French JR, Burningham H, Thornhill G, Nicholls RJ (2016) Integrating estuarine, coastal and inner shelf sediment systems in a common conceptual framework as a basis for participatory shoreline management. In: Meadows M, Lin J-C (eds.) Geomorphology and society. Springer (in press).

\section{CESM as a means of identifying potential changes in state}

Much of geomorphology is concerned with the determination or prediction of incremental changes in process rates or morphology. Over short timescales at least, these are increasingly resolved using reductionist modelling founded on fundamental hydrodynamic and sediment transport principles (e.g. Roelvink and Reniers 2012; Villaret et al. 2013). As the scale of investigation is expanded, qualitative changes in state are sometimes encountered. These include changes in some critical aspect of system dynamics (e.g. a shift from flood-dominance to ebb-dominance in an estuary) as well as changes in gross configuration (as in the breaching and detachment and degradation of a spit).



Fig. 11. Normalised interaction probability matrix landforms and human interventions within the entire Suffolk coastal behaviour system. White cells indicate interactions that do not occur in this system map and colour-coded cells show the varying probability of the interactions that do exist. In this visualisation, both directions of any bi-directional linkages are considered to be separate interactions. 
Pre-print: French JR, Burningham H, Thornhill G, Nicholls RJ (2016) Integrating estuarine, coastal and inner shelf sediment systems in a common conceptual framework as a basis for participatory shoreline management. In: Meadows M, Lin J-C (eds.) Geomorphology and society. Springer (in press).

Phillips (2014) presents a comprehensive overview of the various forms of state change encountered in geomorphic systems more generally. Some are prevalent enough in coastal and estuarine settings to merit immediate attention from landform behaviour modellers. The most straightforward case involves a sequential transition between discrete states, as in the classic tidal flat, lower saltmarsh, upper saltmarsh sequence. A second case involves a sequence that repeats in a cyclical manner; examples are some circumstances of tidal flat - saltmarsh alternation (Pedersen and Bartholdy 2007; Singh Chauhan 2009) or bypassing cycles that involve growth, detachment, migration and reattachment of inlet sediment shoals (Burningham and French 2006). Other important modes of state change involve either divergent or convergent evolution. Divergence is of particular interest in that it implies the existence of multiple evolutionary pathways that may culminate in alternative stable states. An important example in the present context is the potential for evolution towards either wave- or tide-dominated intertidal sedimentation (Fagherazzi and Wiberg 2009; Kirwan et al. 2010). Here, state changes may simultaneously encompass both changes in configuration (e.g. replacement of tidal flat by saltmarsh or vice-versa) and shifts in process dynamics (e.g. a shift from estuary sediment import to export; French et al. 2008). Configuration state changes, such as the breaching of coastal barriers, are not especially prevalent at sub-annual to low interannual timescales but may be significant at decadal to centennial scales (e.g. Orford and Jennings 2007).

We see considerable potential in the application of CESM to identify alternative future states based on the formalisation of our knowledge of particular geographical contexts. By way of illustration, Figure 12 shows the potential for locally divergent coastal futures on a stretch of the Suffolk coast that comprised alternating soft rock headlands punctuated by short sections of gravel barrier beach backed by shallow brackish lagoons (Spencer and Brooks 2012). Here, system mapping (simplified for illustrative purposes) depicts a possible change in configuration at the landform scale arising from a persistent breaching of one of the low gravel barriers, leading to the formation of a new tidal inlet. In modelling terms, this could be handled through an adaptive composition of coupled model codes, in which breaching is evaluated in terms of forcing and state parameters (e.g. using the Barrier Inertia Method; Obhrai et al. 2008) the likely persistence of any barrier breach is evaluated using an inlet stability analysis and, if necessary, a tidal inlet model is then invoked to handle the creation of a new complex of this class.

\section{Integrating geomorphology, engineering and society in participatory coastal and estuary management}

The challenge of coastal and estuarine management is not simply one of devising models that can generate scientifically satisfying answers to questions generated by experts in the field of climate change science. Such efforts are clearly vital but, as in other areas of convergence between environmental science and policy, coastal problems increasingly require the combining of natural and social science perspectives and scientific and lay knowledges to achieve politically and socially acceptable solutions. One aspect of this convergence has been the emergence of participatory modelling as means of achieving meaningful engagement between scientists, policy makers and stakeholders (Voinov and Bousquet, 2010; Gray et al. 2014). There are several strands to this process. Firstly, communication is of paramount importance as science has become almost wholly founded on models. Hall et al. (2014) draw parallels with climate science, 
Pre-print: French JR, Burningham H, Thornhill G, Nicholls RJ (2016) Integrating estuarine, coastal and inner shelf sediment systems in a common conceptual framework as a basis for participatory shoreline management. In: Meadows M, Lin J-C (eds.) Geomorphology and society. Springer (in press).

where public understanding and confidence have been impaired by poor communication of the nature and purpose of simulation models. They further observe that it is not just articulation of the technical aspects of model formulation and application that are important, but also the provision of clear and unambiguous explanatory definitions for the basic concepts that underpin them. Qualitative modelling has a clear role as a means of arriving at shared understanding of the system being studied and the nature of the problems that need to be addressed (e.g. Sano et al. 2014). We see CESM emerging as an effective tool for identifying the most important processes (and associated management issues) to be included in more quantitative modelling studies.
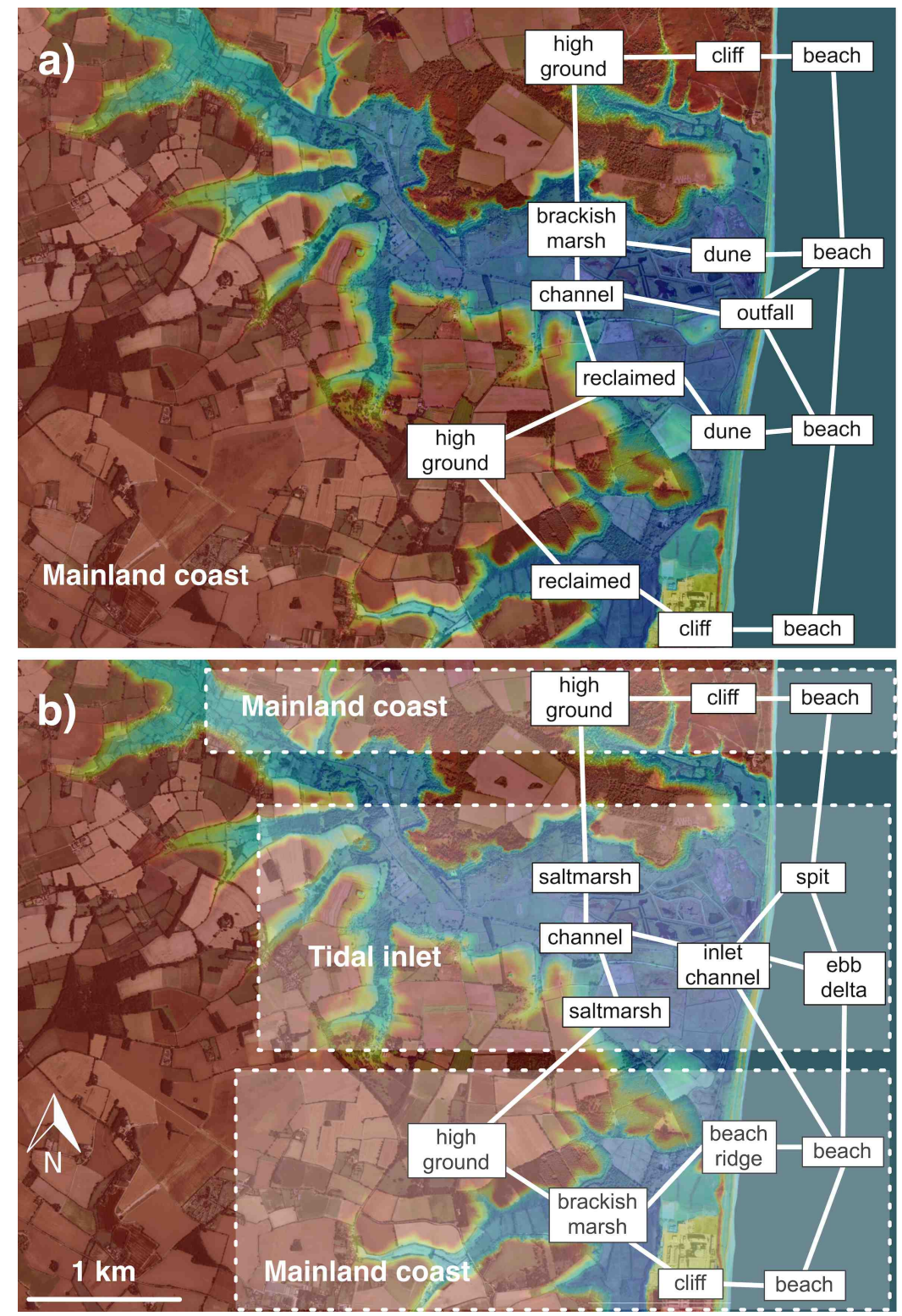

Fig. 12. Highly simplified mapping of a $5 \mathrm{~km}$ stretch of the Suffolk coast, eastern UK, illustrating a) a current mainland coast complex, dominated by a barrier beach backed by alternation of brackish lagoons and elevated cliff headlands; and b) a potential future configuration following hypothetical barrier breaching and the creation of permanent tidal inlets. 
Pre-print: French JR, Burningham H, Thornhill G, Nicholls RJ (2016) Integrating estuarine, coastal and inner shelf sediment systems in a common conceptual framework as a basis for participatory shoreline management. In: Meadows M, Lin J-C (eds.) Geomorphology and society. Springer (in press).

As Hall et al. (2014) observe, it is equally important to achieve some fusion of scientific and lay conceptualisations of how the world works. The CESM approach is intended, at least in part, to engage with this challenge. It has the advantage of rendering the complexity of coastal and estuarine geomorphological systems as a fairly simple ontology of components and interactions, and depicting these in a visual form that provides a highly effective catalyst for discussion and debate between scientist, stakeholder agencies and organisations, and local citizens (Figure 13). Within the iCOASST project (Nicholls et al. 2012), system maps have been enthusiastically received by a diverse group of stakeholders that includes, inter alia, management agencies and regional authorities, non-governmental organisations, representatives of industry and agriculture, and local inhabitants. In the case of the Suffolk study region, discussions have centred on matters of detail, such as the omission of local geological controls on shoreline position, as well as broader scale divergences in opinion - notably concerning the consistency of the littoral drift direction (see also French and Burningham, 2015). These discussions have been extremely valuable in capturing stakeholder knowledge and feeding this into both data-driven analyses and modelling studies. As Schmolke et al. (2010) have argued elsewhere, the capturing of valuable local knowledge and its incorporation into the formulation of a problem and an approach to it, are key elements of good modelling practice that have all too often be neglected.

In contrast to many of the predictive models traditionally used by engineering consultants, CESM is transparent and accessible to a wide range of users. This is partly a consequence of its implementation in open-source software. This counters one of the major shortcomings of a top down' approach to shoreline management planning that has historically been heavily reliant on proprietary closed-source model codes and GIS software that is available to the larger consultancies but not to local communities and smaller consultants. The open source paradigm of computer science is a good model here (Voinov and Gaddis, 2008), in that it demonstrates the benefits of genuine community effort, both in terms of transparency and accessibility and also in terms of legacy. CESM has the potential to create conceptual models that are community efforts, thereby stimulating a greater sense of shared endeavour between modellers and stakeholders than has thus far been possible. The outputs of too many major projects (including, in the UK, the FutureCoast project; Burgess et al. 2002) have become fossilised and inaccessible within a closed data and proprietary software model. The greater accessibility of CESM allows conceptual models and linked databases to evolve beyond individual project timelines through the continuing involvement of a community of researchers and stakeholders. The system maps thus constitute information products that are not finalised at a project end date but, instead, remain free to evolve as knowledge accumulates and agendas change over time. 
Pre-print: French JR, Burningham H, Thornhill G, Nicholls RJ (2016) Integrating estuarine, coastal and inner shelf sediment systems in a common conceptual framework as a basis for participatory shoreline management. In: Meadows M, Lin J-C (eds.) Geomorphology and society. Springer (in press).

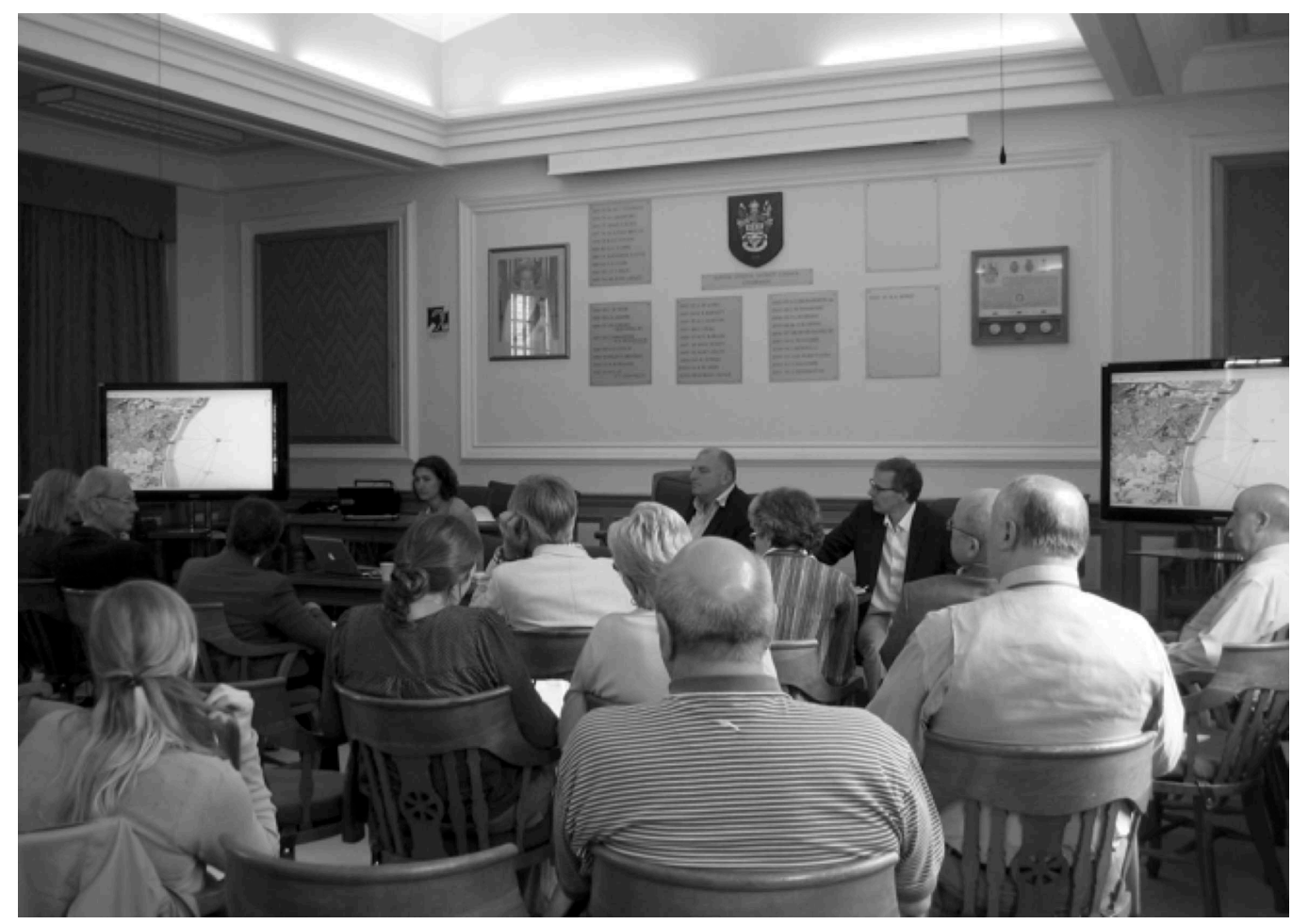

Fig. 13. CESM being used to structure stakeholder discussion relating to the contemporary functioning of part of the Suffolk coast and estuary system as part of the iCOASST project (photo by Alice Milner).

\section{Conclusions}

Geomorphology is pivotal to understanding how coasts and estuaries, and their associated populations and infrastructures, will be impacted by climate change at decadal to centennial scales. Our success in predicting and then adapting to these impacts will be substantially determined by our success in developing better quantitative models of landform change. At the same time, it is vital that our conceptual frameworks allow us to formulate management problems in a scientifically meaningful way. This problem is compounded by the pervasive influence of human agency on contemporary shorelines and by the multitude of stakeholders involved and their differing interests. Effective translation of research into policy requires frameworks that formalise scientific understanding of human - environment systems in a transparent and accessible way and also permit the assimilation of diverse lay knowledges as a basis for a more participatory approach to management planning.

Our approach to Coastal and Estuarine System Mapping (CESM) is intended to contribute to this interface between science, policy and management by offering a geomorphological framework that resolves a more complete web of interactions than the littoral cell-based mapping that has hitherto guided shoreline management planning. Preliminary work with CESM as an opensource geospatial software tool demonstrates potential on several important fronts. Firstly, a hierarchical landform ontology integrates estuary, coast and parts of the inner shelf in a coherent conceptual scheme that is able to accommodate multi-scale sediment sharing pathways and explicitly resolves the localized human interventions that constrain their natural 
Pre-print: French JR, Burningham H, Thornhill G, Nicholls RJ (2016) Integrating estuarine, coastal and inner shelf sediment systems in a common conceptual framework as a basis for participatory shoreline management. In: Meadows M, Lin J-C (eds.) Geomorphology and society. Springer (in press).

operation. Secondly, the mapping process constitutes a form of knowledge formalisation in which disparate sources of information (published research, imagery, mapping, plain data etc.) are generalised into a conceptual model of geomorphological system configuration that can guide the development and application of predictive models. Thirdly, configurational state changes (such as the creation of a new estuary following barrier overtopping and breaching) are not handled well by reductionist hydrodynamic and sediment transport models. The conceptual framework provided by CESM encourages such instances to be identified, a priori, such that divergences in geomorphic system state can be incorporated explicitly into adaptive compositions of coupled landform behaviour models. Conceptualising the spatial structure of a geomorphological system in advance of model development and application allows for locally divergent changes in configuration to be anticipated in the design of compositions of coupled models. This paves the way for exciting new broader-scale simulations of coastal behaviour that go beyond incremental changes in position and rate. Finally, CESM articulates scientific understanding of the structure and function of complex geomorphological systems in a way that is transparent and accessible to diverse stakeholder audiences. As our predictive models of mesoscale landform behaviour increase in ambition and sophistication, this provides a platform on which to build a much more participatory approach to the conduct and communication of model-based coastal and estuarine science and management.

\section{Acknowledgements}

The ideas presented here stem from work initially funded by the Environment Agency for England and Wales under project SC0060074 'Large-scale coastal geomorphological behaviour'. Refinement of the approach and software development has been funded by NERC as part of the UCL contribution to the Integrating COAstal Sediment SysTems (iCOASST) project (NE/J005541/1). We also gratefully acknowledge the comments of two reviewers, which improved the final manuscript.

\section{References}

ABPmer (2008) Development and demonstration of systems-based estuary simulators. R\&D Technical Report FD2117/TR. Defra, London.

Allen JR (1981) Beach erosion as a function of variations in the sediment budget, Sandy Hook, New Jersey, USA. Earth Surf Proc Landf 6:139:150.

Antia EE (1996) Rates and patterns of migration of shoreface-connected sandy ridges along the southern North Sea coast. J Coastal Res 12:38-46.

Barnard PL (2013) Sediment transport patterns in the San Francisco Bay Coastal System from cross-validation of bedform asymmetry and modeled residual flux. Mar Geol 345:72-95.

Barnard PL, Hubbard DM, Dugan JE (2012) Beach response dynamics of a littoral cell using a 17year single-point time series of sand thickness. Geomorphology 139-140: 588-598.

Basco DR (2006) Seawall impacts on adjacent beaches: separating fact and fiction. J Coast Res 39:741-44. 
Pre-print: French JR, Burningham H, Thornhill G, Nicholls RJ (2016) Integrating estuarine, coastal and inner shelf sediment systems in a common conceptual framework as a basis for participatory shoreline management. In: Meadows M, Lin J-C (eds.) Geomorphology and society. Springer (in press).

Batten BK, Blanton B, Taylor S, Plummer J (2015) Modeling the influence of sea level rise on future storm surge elevations considering landscape evolution. In: Wang P, Rosati JD, Cheng J (Eds.) Proceedings Coastal Sediments 2015, World Scientific, New Jersey, 15pp.

Belderson RH (1986) Offshore tidal and non-tidal sand ridges and sheets: differences in morphology and hydrodynamic setting. In: Knight RJ, McLean JR (eds) Shelf sands and sandstones. Canadian Society of Petroleum Geologists. Memoir II, 293-301.

Bernatchez P, Fraser C (2012) Coastal defence structures and consequences for beach width trends, Quebec, Canada. J Coast Res 28:1550-1566.

Bowen AJ, Inman DL (1966) Budget of littoral sands in the vicinity of Point Arguello, California. US Army Coastal Engineering Research Center Technical Memorandum 19, 41pp.

Bray MJ (1997) Episodic shingle supply and the modified development of Chesil Beach, England. J Coast Res 4:1035-1049.

Bray MJ, Carter DJ, Hooke JM (1995) Littoral cell definition and budgets for central southern England. J Coast Res 11:381-400.

Brooks SM, Spencer T (2014) Importance of decadal scale variability in shoreline reponse: examples from soft rock cliffs, East Anglian coast, UK. J Coast Conserv 18:581-593

Browder AG, McNinch JE (2006) Linking framework geology and nearshore morphology: Correlation of paleo-channels with shore-oblique sandbars and gravel outcrops. Mar Geol 231:141-162.

Brown J, Amoudry LO, Souza AJ, Plater AJ (2015) Residual circulation modelled and the national UK scale to inform coastal evolution models. In: Wang P, Rosati JD, Cheng J (Eds.) Proceedings Coastal Sediments 2015, World Scientific, New Jersey, 15pp.

Brown S, Nicholls RJ, Hanson S et al. (2014) Shifting perspectives on coastal impacts and adaptation. Nature Clim Change 4:752-755.

Brown S, Barton M, Nicholls R (2011) Coastal retreat and/or advance adjacent to defences in England and Wales. J Coast Conserv 15:659-670.

Burgess KA, Jay H, Hosking A (2002) FUTURECOAST: Predicting the Future Coastal Evolution of England and Wales. In: EURCOAST (ed) Proceedings Littoral 2002, EUCC/EURCOAST, p295-301.

Burgess KA, Jay H, Hosking A (2004) FutureCoast: Predicting the future coastal evolution of England and Wales. J Coast Conserv 10:65-71.

Burningham H (2015) Gravel spit-inlet dynamics: Orford Spit, UK. In: Randazzo G, Cooper JAG, Jackson D (eds.) Sand and gravel spits. Coastal Research Library, vol 12, Springer 300p. 
Pre-print: French JR, Burningham H, Thornhill G, Nicholls RJ (2016) Integrating estuarine, coastal and inner shelf sediment systems in a common conceptual framework as a basis for participatory shoreline management. In: Meadows M, Lin J-C (eds.) Geomorphology and society. Springer (in press).

Burningham H, French JR (2015a) Large-scale spatial variability in the contemporary coastal sand and gravel resource, Suffolk, eastern UK. In: Wang P, Rosati JD, Cheng J (eds) Proceedings Coastal Sediments 2015, World Scientific, New Jersey, 15pp.

Burningham H, French JR (2015b). Shoreline - Shoreface Dynamics on the Suffolk Coast. Crown Estate.

Burningham H, French JR (2006) Morphodynamic behaviour of a mixed sand-gravel ebb-tidal delta: Deben estuary, Suffolk, UK. Marine Geology 225:23-44.

Burningham H, French JR (2007) Morphodynamics and sedimentology of mixed-sediment inlets. J Coast Res SI 50:710-715.

Burningham H, French JR (2011) Seabed morphodynamics in a large coastal embayment: 180 years of change in the Greater Thames estuary. Hydrobiologia 672:105-119.

Cañas AJ, Carff R, Hill G et al (2005) Concept maps: Integrating knowledge and information visualization. In: Tergan SO, Keller T (eds) Knowledge and information visualization: searching for synergies. Lecture Notes in Computer Science 3426, 205-219.

Castedo R (2012) A new process-response coastal recession model of soft rock cliffs. Geomorphology 177-178:128-143

Caston VND (1972) Linear sand banks in the southern North Sea. Sedimentology 18:63-78.

Chang S-C, Evans G (1992) Source of sediment and sediment transport on the east coast of England: Significant or coincidental phenomena? Mar Geol 107:283-288.

Charlier RH, Chaineux MCP, Morcos S(2011) Panorama of the history of coastal protection. J Coast Res 21:79-111.

Chini N, Stansby P, Leake J et al (2010) The impact of sea level rise and climate change on inshore wave climate: A case study for East Anglia (UK). Coast Eng 57: 973-984.

Clayton KM (1989) Sediment input from the Norfolk cliffs, eastern England - a century of coast protection and its effect. J Coast Res 5:433-442.

Cooper NJ, Pethick JS (2005) Sediment budget approach to addressing coastal erosion problems in St. Ouen's Bay, Jersey, Channel Islands. J Coast Res 21:112-122.

Cooper NJ, Pontee NI (2006) Appraisal and evolution of the littoral 'sediment cell' concept in applied coastal management: experiences from England and Wales. Ocean Coast Manage 49:498-510.

Cowell PJ, Stive MJF, Niedoroda AW et al (2003). The coastal-tract (Part 1): a conceptual approach to aggregated modeling to lower-order coastal change. J Coast Res 19:812827. 
Pre-print: French JR, Burningham H, Thornhill G, Nicholls RJ (2016) Integrating estuarine, coastal and inner shelf sediment systems in a common conceptual framework as a basis for participatory shoreline management. In: Meadows M, Lin J-C (eds.) Geomorphology and society. Springer (in press).

Cowell PJ, Thom BG (1994) Morphodynamics of coastal evolution. In: Carter RWG, Woodroffe CD (eds) Coastal evolution: Late Quaternary shoreline morphodynamics. Cambridge, Cambridge University Press, p33-86.

Dastgheib A, Roelvink JA, Wang ZB (2008) Long- term process-based morphological modeling of the Marsdiep Tidal Basin. Mar Geol 256:90-100.

Davidson NC, Buck AL (1997) An inventory of UK estuaries. In: Introduction and Methodology, vol. 1 Joint Nature Conservation Committee, Peterborough, UK, 46pp.

Davies JL (1974) The coastal sediment compartment. Aust Geog Stud 12:139-151.

Dawson RJ, Dickson ME, Nicholls RJ et al (2009) Integrated analysis of risks of coastal flooding and cliff erosion under scenarios of long term change. Clim Change 95:249-284.

Dolphin TJ, Vincent CE, Coughlan C et al (2007) Variability in sandbank behaviour at decadal and annual time-scales and implications for adjacent beaches. J Coast Res 50:731-737.

Dronkers J, Van Alphen JSLJ, Borst JC (1990) Suspended sediment transport processes in the southern North Sea. In: Cheng RT (ed) Residual currents and long-term transport. Coastal and Estuarine Studies, vol. 38. New York, Springer-Verlag, p302-320.

Dyer KR, Huntley DA (1999) The origin, classification and modelling of sand banks and ridges. Cont Shelf Res 18:1311-1131.

Dyer KR, Moffat TJ (1998) Fluxes of suspended matter in the East Anglian plume, southern North Sea. Cont Shelf Res 19:1285-1330.

Fagherazzi S, Wiberg PL (2009) Importance of wind conditions, fetch, and water levels on wavegenerated shear stresses in shallow intertidal basins. J Geophy Res 114:F03022.

Fenster MS, Dolan R (1993) Historical shoreline trends along the Outer Banks, North Carolina: processes and responses. J Coast Res 9:172-188.

French JR (2008) Hydrodynamic modelling of estuarine flood defence realignment as an adaptive response to sea-level rise. J Coast Res 24-2B:1-12

French JR, Benson T, Burningham H (2008) Tidal and meteorological forcing of suspended sediment flux in a muddy mesotidal estuary. Estuar Coast 31:843-859.

French JR, Burningham H (2009) Mapping the connectivity of large scale coastal geomorphological systems: Coastal system mapping with CmapTools tutorial. Science Report-SC060074/PR2. Bristol, Environment Agency, 25pp.

French JR, Burningham H (2013) Coasts and climate: insights from geomorphology. Progress in Physical Geography 37, 550-561. 
Pre-print: French JR, Burningham H, Thornhill G, Nicholls RJ (2016) Integrating estuarine, coastal and inner shelf sediment systems in a common conceptual framework as a basis for participatory shoreline management. In: Meadows M, Lin J-C (eds.) Geomorphology and society. Springer (in press).

French JR, Burningham H (2015) Wave-driven sediment pathways on a gravel-dominated coast subject to a strongly bi-modal wave climate. In: Wang P, Rosati JD, Cheng J (Eds.) Proceedings Coastal Sediments 2015, World Scientific, New Jersey, 15pp.

French JR, Burningham H, Thornhill G et al (2016a) Conceptualizing and mapping coupled estuary, coast and inner shelf sediment systems. Geomorphology 256:17-35

French JR, Payo A, Murray AB et al (2016b) Appropriate complexity for the prediction of coastal and estuarine geomorphic behaviour at decadal to centennial scales. Geomorphology 256:3-16

Funnell BM, Boomer I, Jones R (2000) Holocene evolution of the Blakeney Spit area of the Norfolk coastline. Proc Geol Assoc 111:205-217.

Gelbaum G, Kaminsky GM (2010) Large-scale coastal change in the Columbia River littoral cell: An overview. Mar Geol 273:1-10.

Gerritsen H, Vos RJ, van der Kaaij T et al (2000) Suspended sediment modelling in a shelf sea (North Sea). Coast Eng 41:317-352.

Gray SRJ, Gagnon AS, Gray SA et al (2014) Are coastal managers detecting the problems? Assessing stakeholder perception of climatic vulnerability using Fuzzy Cognitive Mapping. Ocean Coast Manage 94:74-89

Gruber TR (1993) A translation approach to portable ontology specifications. Knowledge Aquis 5:199-220.

Hall DM, Lazarus ED, Swannack TM (2014) Strategies for communicating systems models. Env Model Software 55:70-76.

Hanley ME, Hoggart SPG, Simmonds DJ et al (2014) Shifting sands? Coastal protection by sand banks, beaches and dunes. Coast Eng 87:136-146.

Hanson S, Nicholls RJ, Balson P et al (2010) Capturing coastal geomorphological change within regional integrated assessment: an outcome-driven fuzzy logic approach. J Coast Res 26:831-842.

Hapke CJ, Lentz EA, Gaye PT et al (2010) A review of sediment budget imbalances along Fire Island, New York: can nearshore geologic framework and patterns of shoreline change explain the deficit? J Coast Res 26:510-522.

Hapke CJ, Kratzmann MG, Himmelstoss EA (2013) Geomorphic and human influence on largescale coastal change. Geomorphology 199:160-170.

Harpham Q, Cleverley P, Kelly D (2014) The FluidEarth 2 implementation of OpenMI 2.0. J Hydroinfo 16:890-906. 
Pre-print: French JR, Burningham H, Thornhill G, Nicholls RJ (2016) Integrating estuarine, coastal and inner shelf sediment systems in a common conceptual framework as a basis for participatory shoreline management. In: Meadows M, Lin J-C (eds.) Geomorphology and society. Springer (in press).

Harris MS, Sautter LR, Johnson KL et al (2013) Continental shelf landscapes of the southeastern United States since the last interglacial. Geomorphology 203:6-24.

Hequette A, Aernouts D (2010) The influence of nearshore sand bank dynamics on shoreline evolution in a macrotidal environment, Calais, northern France. Cont Shelf Res 30:13491361.

Hequette A, Hemdane Y, Anthony E (2008) Sediment transport under wave and current combined flows on a tide-dominated shoreface, northern coast of France. Mar Geol 249:226-242

Hibma A, Schuttelaars HM, de Vriend HJ (2004) Initial formation and long term evolution of channel-shoal patterns. Cont Shelf Res 24:1637-1650

Hinkel J, Linke D, Vafeidis AT, Perrette M, Nicholls RJ, Tol RSJ, Marzeion B, Fettweis X, lonescu C, Levermann A (2014) Coastal flood damage and adaptation costs under 21st century sealevel rise. PNAS 111, 3292-3297.

Hitchcock DR, Bell S (2004) Physical impacts of marine aggregate dredging on seabed resources in coastal deposits. J Coast Res 20:101-114.

Hsu J ,Yu MJ, Lee FC, Benedet L (2010). Static bay beach concept for scientists and engineers: a review. Coast Eng 57:76-91.

Huang ZG, Zong YQ, Zhang WQ (2004) Coastal inundation due to sea level rise in the Pearl River Delta, China. Nat Hazard 33:247-264.

Hume TM, Herdendorf CE (1988) A geomorphic classification of estuaries and its application to coastal resource management - A New Zealand example. J Ocean Shore Manage 11:249274.

Hume TM, Snelder T, Weatherhead M et al (2007) A controlling factor approach to estuary classification. Ocean Coast Manage 50:905-929.

Hunt S, Guthrie G, Cooper N et al (2011) Estuaries and Shoreline Management Plans - lessons learned from Round 2. Proceedings Littoral 2010, London. EDP Sciences 06003, 1-8. DOI:10.1051/litt/201106003

Inman DL, Frautschy JD (1966) Littoral processes and the development of shorelines. In: Proceedings of the Coastal Engineering Speciality Conference, Santa Barbara, California. American Society of Civil Engineers, p511-536.

Kana TW (1995) A meso-scale sediment budget for Long Island, New York. Mar Geol 126:87-110.

Keen TR, Slingerland RL (2006) Potential transport pathways of terrigenous material in the Gulf of Papua. Geophys Res Lett 33:L04608. 
Pre-print: French JR, Burningham H, Thornhill G, Nicholls RJ (2016) Integrating estuarine, coastal and inner shelf sediment systems in a common conceptual framework as a basis for participatory shoreline management. In: Meadows M, Lin J-C (eds.) Geomorphology and society. Springer (in press).

Khalil SM, Finkl CW, Roberts HH (2010) New approaches to sediment management on the inner continental shelf offshore coastal Louisiana. J Coast Res 26:591-604.

Kirby R (1987) Sediment exchanges across the coastal margins of NW Europe. J Geol Soc 144:121-126.

Kirwan ML, Guntenspergen GR, D'Alpaos A et al (2010) Limits on the adaptability of coastal marshes to rising sea level. Geophysical Research Letters 37:L23401.

Komar PD (1996) The budget of littoral sediments: concepts and applications. Shore \& Beach 64:18-26.

Komar PD (2010) Shoreline evolution and management of Hawke's Bay, New Zealand: tectonics, coastal processes and human impacts. J Coast Res 26:143-156.

Kragtwijk N, Zitman T, Stive M et al (2004) Morphological response of tidal basins to human interventions. Coast Eng 51: 207-221.

Kron W (2013) Coasts: the high-risk areas of the world. Nat Hazard 66:1363-1382.

Leafe R, Pethick J, Townend I (1998) Realizing the benefits of shoreline management. Geog J 164:282-290.

Lichter M, Vafeidis AT, Nicholls RJ et al (2011) Exploring data-related uncertainties in analyses of land area and population in the 'Low-Elevation Coastal Zone' (LECZ). J Coast Res 27:757768.

Luo S, Cai F, Liu H et al (2015) Adaptive measures adopted for risk reduction of coastal erosion in the People's Republic of China. Ocean Coast Manage 103:134-145.

McCave IN (1987) Fine sediment sources and sinks around the East Anglian Coast (UK). J Geol Soc 144:149-152.

MacDonald N, O'Connor B (1994) Influence of offshore banks on the adjacent coast. Coast Eng Proc 1: 492-504.

McGranahan G, Balk D, Anderson B (2007) The rising tide: Assessing the risks of climate change and human settlements in low elevation coastal zones. Env Urban 19:17-37.

McNinch JE (2004) Geologic control in the nearshore: shore-oblique sandbars and shoreline erosion hotspots, Mid-Atlantic Bight, USA. Mar Geol 211:121-141.

Motyka JM, Brampton AH (1993) Coastal management: mapping of littoral cells. Hydraulics Research Ltd, Wallingford, UK, Wallingford Report SR 328, 102pp.

Mulder JPM, Hommes S, Horstman EM (2011) Implementation of coastal erosion management in the Netherlands. Ocean Coast Manage 54:888-897. 
Pre-print: French JR, Burningham H, Thornhill G, Nicholls RJ (2016) Integrating estuarine, coastal and inner shelf sediment systems in a common conceptual framework as a basis for participatory shoreline management. In: Meadows M, Lin J-C (eds.) Geomorphology and society. Springer (in press).

Murray AB, Lazarus E, Ashton A et al (2008) Geomorphology, complexity, and the emerging science of the Earth's surface. Geomorphology 103:496-505.

Narayan S, Hanson S, Nicholls RJ et al (2012) A holistic model for coastal flooding using system diagrams and the source-pathway-receptor (SPR) concept. Nat Hazard Earth System Sci 12:1431-1439.

Nicholls RJ (2011) Planning for the impacts of sea level rise. Oceanography 24:144-157.

Nicholls RJ, Bradbury A, Burningham $\mathrm{H}$ et al (2012) iCOASST - integrating coastal sediment systems. Coastal Engineering Proceedings 1(33):100.

Nicholls RJ, Lowe JA (2004) Benefits of mitigation of climate change for coastal areas. Global Env Change 14:229-244.

Nicholls RJ, Townend IH, Bradbury AP et al (2013) Planning for long-term coastal change: experience from England and Wales. Ocean Eng 71:3-16.

Nordstrom KF (2014) Living with shore protection structures: a review. Est Coast Shelf Sci 150:11-23.

Obhrai C, Powell KA, Bradbury AP (2008) A laboratory study of overtopping and breaching of shingle barrier beaches. In: Proceedings of the 31st International Conference on Coastal Engineering, Hamburg, Germany. World Scientific.

Orford JD, Jennings SC (2007) Variation in the organisation of gravel-dominated coastal systems: Evidence from Nova Scotia and Southern England. Proceedings Coastal Sediments '07. New Orleans. American Society of Civil Engineers, vol. 1: 434-448.

Park J-Y, Wells JT (2005) Longshore transport at Cape Lookout, North Carolina: shoal evolution and the regional sediment budget. J Coast Res 21:1-17.

Pedersen JBT, Bartholdy J (2007) Exposed salt marsh morphodynamics: an example from the Danish Wadden Sea. Geomorphology 90:115-125.

Phillips JD (2012) Synchronization and scale in geomorphic systems. Geomorphology 137:50-58.

Phillips JD (2014) State transitions in geomorphic responses to environmental change. Geomorphology 204:208-217.

Plater AJ, Stupples P, Roberts HH (2009) Evidence of episodic coastal change during the Late Holocene: The Dungeness barrier complex, SE England. Geomorphology 104:47-58.

Poulos SE, Ballay A (2010) Grain-size trend analysis for the determination of non-biogenic sediment transport pathways on the Kwinte Bank (southern North Sea), in relation to sand dredging. J Coast Res SI 51:95-100. 
Pre-print: French JR, Burningham H, Thornhill G, Nicholls RJ (2016) Integrating estuarine, coastal and inner shelf sediment systems in a common conceptual framework as a basis for participatory shoreline management. In: Meadows M, Lin J-C (eds.) Geomorphology and society. Springer (in press).

Psuty NB, Pace J (2009) Sediment management at Sandy Hook, NJ: An interaction of science and public policy. Geomorphology 104:12-21.

Robinson AHW (1966) Residual currents in relation to shoreline evolution of the East Anglian coast. Mar Geol 4: 57-84.

Roelvink D, Reniers A (2012) A guide to modeling coastal morphology. World Scientific, New Jersey.

Ruggiero P, Walstra DJR, Gelfenbaum G (2009) Seasonal-scale nearshore morphological evolution: field observations and numerical modeling. Coast Eng 56:1153-1172

Runyan K, Griggs GB (2003) The effects of armoring seacliffs on the natural sand supply to the beaches of California. J Coast Res 19: 336-347.

Sanò M, Richards R, Medina R (2014) A participatory approach for system conceptualization and analysis. Environ Model Software 54:142-152.

Sayers PB, Hall JW, Meadowcroft IC (2002) Towards risk-based flood hazard management in the UK. Proceed Inst Civil Eng 150:36-42.

Schmidt T, Mitchell NC, Ramsay TS (2007) Use of swath bathymetry in the investigation of sand dune geometry and migration around a near shore 'banner' tidal sandbank. In: Balson PS, Collins MB (eds) Coastal and shelf sediment transport. Geological Society Special Publication 274, 53-64.

Schmolke A, Thorbeck P, DeAngel DL (2010) Ecological models supporting environmental decision making: a strategy for the future. Trend Ecol Evolut 25:479-486.

Shih S-M, Komar PD (1994) Sediments, beach morphology and sea cliff erosion within an Oregon coastal littoral cell. J Coast Res 10:144-157.

Singh Chauhan PP (2009) Autocyclic erosion in tidal marshes. Geomorphology 110:45-57.

Smits AJM, Nienhuis PH, Saeijs HLF (2006) Changing estuaries, changing views. Hydrobiologia 565:339-355.

Spencer T, Brooks SM (2012) Methodologies for measuring and modelling change in coastal saline lagoons under historic and accelerated sea-level rise, Suffolk coast, eastern England. Hydrobiologia 693:99-115.

Stapor FW (1973) History and sand budgets of the barrier island system in the Panama City, Florida, region. Mar Geol 14:277-286.

Stive MJF, Capobianco M, Wang B (1998) Morphodynamics of a tidal lagoon and adjacent coasts. In: Proceedings 8th International Conference on Physics of Estuaries and Coastal Seas. The Hague. Balkema, Rotterdam, p397-407. 
Pre-print: French JR, Burningham H, Thornhill G, Nicholls RJ (2016) Integrating estuarine, coastal and inner shelf sediment systems in a common conceptual framework as a basis for participatory shoreline management. In: Meadows M, Lin J-C (eds.) Geomorphology and society. Springer (in press).

Storlazzi CD, Field ME (2000) Sediment distribution and transport along a rocky, embayed coast: Monterey Peninsula and Carmel Bay, California. Mar Geol 170:289-316.

Stul T, Gozzard JR, Eliot IG et al (2012) Coastal sediment cells between Cape Naturaliste and the Moore River, Western Australia. Report prepared by Damara WA Pty Ltd and Geological Survey of Western Australia for the Western Australian Department of Transport, Fremantle.

Swift DJP, Field ME (1981) Evolution of a classic sand ridge field: Maryland sector, North American inner shelf. Sedimentology 28:461-482.

Van der Kreeke J, Hibma A (2005) Observations on silt and sand transport in the throat section of the Frisian Inlet. Coast Eng 52:59-175.

Van der Wegen M, Roelvink JA (2008) Long-term morphodynamic evolution of a tidal embayment using a two-dimensional, process-based model. J Geophys Res 113(C3016):1-23.

Van Koningsveld M, Mulder JPM, Stive MJF et al (2008) Living with sea-level rise and climate change: A case study of the Netherlands. J Coast Res 24:367-379.

van Lancker V, Lanckneus J, Hearn S et al (2004) Coastal and nearshore morphology, bedforms and sediment transport pathways at Teignmouth (UK). Cont Shelf Res 24:1171-1202

Van Rijn LC, Ribberink JS, Van der Werf J et al (2013) Coastal sediment dynamics: recent advances and future research needs. J Hydraul Res 51:475-493.

Van Slobbe E, de Vriend HJ, Aarninkhof S et al (2013) Building with Nature: in search of resilient storm surge protection strategies. Nat Hazards 65:947-966.

Villaret C, Hervouet J-M, Kopmann R et al (2013) Morphodynamic modelling using the Telemac finite-element system. Computer \& Geosci 53:105-113.

Voinov A, Bousquet F (2010) Modelling with stakeholders. Env Model \& Software 25:1268-1281.

Voinov A, Gaddis EB (2008) Lessons from successful participatory watershed modelling: a perspective from modelling practitioners. Ecol Model 216:197-207.

Walkden M, Hall J (2011) A mesoscale predictive model of the evolution and management of a soft-rock coast. J Coast Res 27:529-543.

Walkden MJ, Payo A, Barnes J, Burningham H (2015) Modeling the response of coupled barrier and cliff systems to sea level rise. In: Wang P, Rosati JD, Cheng J (Eds.) Proceedings Coastal Sediments 2015, World Scientific, New Jersey, 15pp.

Walstra DJR, Hoekstra R, Tonnon PK et al (2013) Input reduction for long-term morphodynamic simulations in wave-dominated coastal settings. Coast Eng 77:57-70. 
Pre-print: French JR, Burningham H, Thornhill G, Nicholls RJ (2016) Integrating estuarine, coastal and inner shelf sediment systems in a common conceptual framework as a basis for participatory shoreline management. In: Meadows M, Lin J-C (eds.) Geomorphology and society. Springer (in press).

Werner BT (2003) Modeling landforms as self-organized, hierarchical dynamical systems. In: Wilcock PR, Iverson RM (eds) Prediction in geomorphology. Geophysical Monograph 135, American Geophysical Union, 133-150.

Wetzel MA, Scholle J, Teschke K (2014) Artificial structures in sediment-dominated estuaries and their possible influences on the ecosystem. Mar Env Res 99:125-135. 